\title{
LA AUTONOMÍA DE LA INDEMNIZACIÓN DE DAÑOS EN LA JURISPRUDENCIA NACIONAL RECIENTE: ¿UN CAMBIO DE PARADIGMA?
}

\section{THE AUTONOMY OF DAMAGES IN THE RECENT NATIONAL CASE LAW: A PARADIGM SHIFT?}

Patricia Verónica López Díaz"

\section{Resumen}

El presente trabajo tiene por finalidad abordar la autonomía de la indemnización de daños por incumplimiento contractual en la jurisprudencia nacional reciente, analizando, sistematizando y determinando la pertinencia de las premisas o argumentos que han invocado los tribunales nacionales para admitir la indemnización exclusiva frente a la inejecución del deudor, alejándose del razonamiento judicial que durante décadas postuló que la indemnización solo podía demandarse como una acción o remedio accesorio, concurrente o complementario a la pretensión de cumplimiento específico o a la resolución del contrato.

Palabras clave: autonomía de la indemnización de daños, libre opción del acreedor, reparación integral.

\section{AbSTRACT}

The current work aims to tackle the autonomy of damages compensation for breach of contract within the current national precedent, by analyzing, systematizing and determining the pertinence of the premises and arguments that have been cited by the national courts to hold autonomy damages against breach of a debtor, getting away from the judicial rea-

* Licenciada en Ciencias Jurídicas y Sociales Universidad Adolfo Ibáñez. Doctora en Derecho Pontificia Universidad Católica de Valparaíso. Profesora de Derecho Civil de la Universidad Andrés Bello, sede Viña del Mar. Docente en la carrera de Derecho, Universidad Adolfo Ibáñez, Viña del Mar. Dirección Postal: Sotomayor 592, $4^{\circ}$ piso, Valparaíso. Artículo recibido el 6 de agosto de 2014 y aceptado para su publicación el 1 de octubre de 2014 . 
soning which, for decades has postulated that this remedy could only be demanded as an accessory action or remedy, concurrent or supplementary to the aspiration of specific performance remedy or termination of contract.

Keywords: Autonomy of damages compensation, Creditor free option, Full repair.

\section{INTRODUCCIÓN}

Un examen de la jurisprudencia nacional revela que a partir del año 1900 los tribunales chilenos han desestimado en forma prácticamente sistemática la procedencia de la indemnización de daños exclusiva por incumplimiento contractual, invocando premisas que hasta hace poco tiempo parecían indubitadas y que permitían sustentar el carácter accesorio, concurrente o complementario de dicha indemnización.

Tal planteamiento motivó que hace algunos años criticáramos esta tendencia jurisprudencial y propusiéramos argumentos destinados a sustentar la autonomía de la indemnización ${ }^{1}$, tales como la interpretación lógica y sistemática de la expresión "con indemnización de perjuicios" 140 del artículo $1489 \mathrm{del} C C$, la inejecución imputable como fundamento de la indemnización, la incorrecta ubicación del artículo 1489 del $C C$ y la reparación integral del daño.

Hoy retomamos este tópico para constatar cuál es el estado actual de la jurisprudencia nacional, advirtiendo que en el último tiempo esta ha reconocido progresivamente el ejercicio autónomo de la indemnización por incumplimiento contractual, controvirtiendo premisas que parecían irrefutables y construyendo el carácter exclusivo o directo de la indemnización a partir de la libre opción del acreedor, el carácter principal de la indemnización y el principio de reparación integral del daño.

En efecto, una revisión de las sentencias pronunciadas por la Corte $\mathrm{Su}-$ prema desde el año 2010 a la fecha, evidencia que dicho tribunal ha acogido, en forma prácticamente invariable, la pretensión indemnizatoria exclusiva a propósito de la inejecución de obligaciones de hacer e inobservancia de obligaciones de dar, pues a la fecha solo hemos detectado una sola sentencia que ha insistido en el carácter concurrente, complementario y accesorio de la indemnización con ocasión de esta última clase de obligaciones ${ }^{2}$.

${ }^{1}$ En tal sentido LóPEz (2010), pp. 85-109.

${ }^{2}$ Véase la sentencia de la Corte Suprema en Cuadra Calderón con Céspedes Arteagabeitía (2013), véase n. 38. Un fenómeno similar se advierte en la sentencia de la Corte de Apelaciones de Valparaíso pronunciada en Muñoz Cerda con MassuMassu (2012), véase n. 48. 
Atendido que desde antiguo la tendencia mayoritaria y predominante en nuestra doctrina y jurisprudencia fue desconocer y desestimar la procedencia exclusiva de la pretensión indemnizatoria, cabe preguntarse si el reconocimiento judicial de tal autonomía constituye un cambio de paradigma que puede afincarse sobre premisas indubitadas o, por el contrario, se trata de una tendencia que carece de consideraciones dogmáticas sólidas que permitan proyectarla en el tiempo. Más aún si la posibilidad de deducir directa o exclusivamente la indemnización de daños ha sido reconocida en forma expresa en los cuerpos normativos de derecho contractual uniforme ${ }^{3}$, proyectos de reforma del Code $e^{4}$, en el borrador de los $\mathrm{PLDC}^{5}$ y admitida en la doctrina francesa ${ }^{6}$, italiana ${ }^{7}$,

${ }^{3}$ En efecto, el artículo 45 de la CVCIM consagra la opción del vendedor entre el cumplimiento específico (sustitución y reparación de mercaderías), la resolución del contrato, la rebaja del precio y la indemnización de daños. En tanto, el artículo 61 de dicha Convención otorga al comprador la facultad de optar entre exigir el cumplimiento, la resolución y la indemnización de daños.

Por otro lado, el artículo 7.4.1 de los PCCI otorga a la parte perjudicada por el incumplimiento un derecho al resarcimiento, ya sea exclusivo o en concurrencia con otras pretensiones, salvo que la inejecución sea excusable de conformidad a tales principios.

Por último, el artículo 8:101(1) de los PECL dispone que siempre que una parte no cumpla con alguna de las obligaciones derivadas del contrato y el incumplimiento no pueda exonerarse por imposibilidad de cumplimiento, la otra puede recurrir a cualquiera de las acciones o remedios dispuestos en el Capítulo 9 y solicitar el cumplimiento, la suspensión de la ejecución de la prestación, la resolución del contrato, la reducción del precio o la indemnización de daños.

${ }^{4} \mathrm{El}$ artículo 1158 del proyecto Catala dispone: "En todo contrato, la parte respecto de la cual el compromiso no ha sido ejecutado, o lo ha sido imperfectamente, tiene la opción o de exigir la ejecución del compromiso o de provocar la resolución del contrato o de reclamar indemnización de daños, a los cuales pueden, llegado el caso añadirse la ejecución o resolución". Por su parte, el artículo 161 del proyecto de la Chancellerie reproduce dicho precepto, al igual que el artículo 97 del proyecto Terré, pero este último agrega la opción del acreedor de suspender la ejecución de su propia obligación y solicitar la reducción del precio.

${ }^{5}$ Dicho borrador elaborado por un grupo de investigadores de Argentina, Brasil, Colombia, Chile, Paraguay, Uruguay y Venezuela, en la última versión del artículo 8:201 (2) prescribe: "La indemnización de daños podrá ejercerse de manera autónoma, o en conjunto con los demás medios de tutela".

${ }^{6} \mathrm{El}$ artículo $1184 \mathrm{del}$ Code, en su parte pertinente, indica: "La condition résolutoire est toujours sous-entendue dans les contrats synallagmatiques, pour le cas oùl'une des deux partiesne satisfera point à son engagement. Dans ce cas, le contratn'est point résolude plein droit. La partie envers la quelle l'engagement n'apointé té exécuté, a le choixou de forcerl'autre à l'exécution de la convention lors qu'elle est possible, oud'endemander la résolution avec dommages et intérêts". La discusión en torno a la autonomía liderada por Paul Grosser, Geneviène Viney y Thomas Genicon hoy se encuentra superada. Cfr. Grosser (2000), p. 494; Viney (2001), pp. 921 y 933 y Genicon (2007), pp. 28-30.

${ }^{7} \mathrm{El}$ inciso primero del artículo 1453 del Codice dispone lo siguiente: "Nei contratti con prestazioni corrispettive, quando uno dei contraenti non adempie le sue obbligazioni, l'altropuò a sua scelta chiedere l'adempimento o la risoluzione del contratto, salvo, in ogni 
colombiana ${ }^{8}$ y venezolana ${ }^{9}$, cuyos Códigos contemplan una norma similar o idéntica a nuestro artículo 1489.

Para resolver esta interrogante se seguirá el siguiente esquema:

I. En primer lugar,se expondrá la argumentación que tradicionalmente han invocado los tribunales nacionales para postular el carácter complementario y dependiente de la indemnización de daños por incumplimiento, aludiendo a los casos en que tal formulación ha tenido lugar y evidenciando los inconvenientes de dicho planteamiento.

II. A continuación, se efectuará una revisión de las causas en que la jurisprudencia nacional ha admitido la indemnización autónoma, exponiendo los hechos constitutivos de cada uno de ellos y analizando si en el caso concreto ésta era procedente

III. Luego, se sistematizarán las premisas a partir de las cuales se ha admitido la procedencia de la indemnización exclusiva, evaluando su pertinencia y determinando si es posible agregar otras que permitan complementarlas

IV. Examinados tales tópicos, se formularán las conclusiones.

I. EL PARADIGMA TRADICIONAL EN LA JURISPRUDENCIA NACIONAL: LA INDEMNIZACIÓN DE DAÑOS COMO ACCIÓN O REMEDIO POR INCUMPLIMIENTO CONTRACTUAL COMPLEMENTARIO, DEPENDIENTE Y ACCESORIO

Una revisión de la doctrina tradicional y de las sentencias pronunciadas por nuestros tribunales permite constatar que a partir del 18 de mayo de 1900 la indemnización de daños se concibió como un medio de tutela que el acreedor solo podía demandar como concurrente, accesorio o dependiente de la pretensión de cumplimiento específico o la resolución.

En efecto, entre los años 1867 a 1894 prevaleció la tendencia jurisprudencial que reconocía la autonomía de la indemnización por inejecu-

caso, ilrisarcimento del danno". A favor de la autonomía Coviello Jr. (1935), p. 31, n. 46; Luminoso (1990), pp. 117-133; Sicchiero (2007), p. 426 y Pinori (2001), pp. 226-240.

${ }^{8}$ En efecto, el tenor literal del artículo 1546 del Código Civil colombiano es idéntico al artículo 1489 de nuestro Código Civil. Admitiendo la autonomía de la indemnización Mantilla-Ternera Barrios (2007), pp. 257-258; Ospina (2001), p. 89; Cubides-Camacho (2009), p. 322 y Oviedo (2009), pp. 209-212.

${ }^{9} \mathrm{El}$ artículo 1167, ubicado en el título II de las Obligaciones a propósito de los efectos del contrato, señala lo siguiente: "En el contrato bilateral, si una de las partes no ejecuta su obligación, la otra puede, a su elección, reclamar judicialmente la ejecución del contrato o la resolución del mismo, con los daños y perjuicios en ambos casos si hubiere lugar a ellos". A favor de la indemnización exclusiva, entre otros, Arismendi (1939), p. 199 y ss.; Kummerow (1999), pp. 272-275 y MÉLICH (2007), pp. 39-46. 
ción. Así lo revelan las sentencias pronunciadas en los casos Barrios con Rozé $^{10}$, Barthet con Paine ${ }^{11}$ y Virgilio y otros con Schiavetti y Hermanos $^{12}$ en las que el principal argumento que se invoca para otorgar la pretensión indemnizatoria directa es el incumplimiento imputable al deudor que causa daños al acreedor.

A pesar de la autoridad de este argumento, dicha tendencia jurisprudencial experimentó un vuelco, subsistiendo la admisibilidad de la indemnización exclusiva en algunos votos disidentes ${ }^{13}$, retomándose solo a partir de

${ }^{10}$ En este caso José María Barrios interpuso una demanda de indemnización de daños por incumplimiento de contrato de fletamento en contra de Juan Rozé, capitán del buque francés Marie Amalie, dado que este no cumplió su obligación de descargar en Centro América mercaderías de propiedad del primero ni tampoco cargó en el puerto de Unión mercaderías surtidas o maderas que se había obligado a transportar a Valparaíso o al puerto más cercano al que pudiere llegar con seguridad. El tribunal, una vez acreditada la infracción del contrato, acoge la pretensión indemnizatoria del demandante, condenándolo al pago de la suma avaluada por peritos, invocando los artículos 1489, 1543, 1557, 1559 y 2207, todos ellos del $C C$ (véase sentencia Barrios con Rozé (1868), pp. 354-355.)

${ }^{11}$ En este caso Wilson Paine contrató los servicios de Juana Barthet para que lo acompañara junto a su familia a Europa. Una vez que ella llegó a Valparaíso para retirar los pasajes de la Compañía Inglesa de Vapores, el señor Paine le comunicó que su esposa había fallecido y que por este motivo había decido poner término al contrato. Juana Barthet interpuso demanda por infracción del contrato, argumentando desistimiento extemporáneo sin causa legítima, precisando que por respetar el acuerdo desechó una oferta formulada por otra familia que también viajaba a Europa y solicita que se declare que el demandado debe satisfacerle la cantidad necesaria para seguir su viaje a Europa en $2^{\circ}$ clase por el precio establecido en las tarifas de la referida compañía. El tribunal, invocando al efecto los artículos 1489, 1698, 1999, 2007 y 2008, todos ellos del $C C$, acoge la demanda y expresa en su considerando sexto que los perjuicios deben consistir en una suma que le reembolse los gastos en que incurrió para cumplir el contrato (véase sentencia Paine con Barthet (1880), p. 1411).

${ }^{12}$ Los hechos de la causa en este caso son los siguientes: Virgilio, Barón y Tifón -cuyos apellidos no se indican en el fallo- compraron a Schiavetti y Hermanos quinientos sacos de lentejas que debían transportar desde Europa a Valparaíso por el vapor Abydos, lo que no ocurrió en la fecha prevista en el contrato. Tal incumplimiento determinó que los compradores demandaran al vendedor indemnización de daños y que la Corte condenara al demandado al pago de aquellos reconocidos en la contestación de la demanda, esto es, la diferencia de precio que experimentó la mercadería contratada entre la celebración del contrato y la salida del vapor desde Europa (véase sentencia Virgilio y otros con Schiavetti y Hermanos (1894), pp. 533-535.)

${ }^{13}$ Véase el voto disidente de los ministros Mariano Fontecilla, Gregorio Schepeler y Alfredo Rondanellien la sentencia de la Corte Suprema con ocasión del caso Warncken con Ferrer de 28 de julio de 1933 en GT, N 5, segundo semestre, 1933 pp. 15-19. En la última década también es posible advertir votos de disidencia, que justifican la autonomía de la indemnización a propósito de la inobservancia de una obligación de hacer. Es el caso del considerando quinto del voto disidente del ministro Sergio Muñoz Gajardo en la sentencia pronunciada por la Corte Suprema en el caso Seguros Generales S.A. con Transportes Aduana Ltda, pues refiriéndose a la inejecución de la obligación de transportar mercaderías, indica que este "otorga al acreedor la acción para solicitar su cumplimiento 
las sentencias pronunciadas por la Corte Suprema en los casos Transportes Aeropuerto Express Ltda. con LADECO S.A. de 16 de agosto de 2007, Instituto de Normalización Previsional con Banco Santander Chile de 26 de diciembre de 2006 y Zorín con Siderúrgica Huachipato S.A. de 31 de octubre de $2012^{14}$, pues en ellas dicho tribunal reconoce la procedencia de la indemnización por incumplimiento tratándose de una obligación de no hacer, de una obligación de hacer y de una obligación de dar, respectivamente ${ }^{15}$.

Dicho vuelco en el razonamiento de nuestros tribunales encontraría explicación, a nuestro juicio, en la gravitante influencia del pensamiento de Efraín Vío Vásquez en la jurisprudencia de aquella época. Y es que según nuestros registros es el primer autor nacional que postuló expresamente el carácter concurrente y complementario de la indemnización de daños, pues ya en el año 1945, sostiene que para que el acreedor pueda demandar indemnización de daños por incumplimiento de un contrato bilateral es requisito esencial que solicite, en carácter de principal, la resolución o el cumplimiento del contrato. En su opinión, la indemnización es una consecuencia de la resolución o la pretensión de cumplimiento específico, de modo que se trata de un derecho accesorio que encuentra su fundamento jurídico en aquellos ${ }^{16}$.

Incluso califica los fallos contrarios a este planteamiento como "anti144 jurídicos", citando los casos Barrios con Rozé, Barthet con Paine yVirgilio y otros con Schiavetti y Hermanos e indicando que ellos contravienen el claro tenor literal del artículo 1489 del Código Civil. Tal postulado, como se verá más adelante, puede resultar en algunos casos, al menos discutible.

forzado en naturaleza y/o por equivalencia, conforme a los términos de los artículos 1489 inciso $2^{\circ}$ y 1553 del Código Civil” (véase sentencia Corte Suprema Seguros Generales S.A. con Transportes Aduana Ltda. (2009).

${ }^{14}$ En lo que concierne a los hechos constitutivos de estos casos véase infra II.1. i), n. 71 y II.1. vii.

${ }^{15}$ Es posible advertir un período intermedio en el que no se reconoce en forma explícita la autonomía de la indemnización, pero se acoge la indemnización aun cuando no se demande en forma concurrente y complementaria. Así se advierte en la sentencia de la Corte Suprema Juica y otros con Liceo San Francisco de Asís y otros (2004) y en la sentencia de la Corte de Apelaciones de SantiagoCarrasco con Clínica Dávila y Servicios Médicos S.A. (2008).

${ }^{16}$ Así, el autor refiriéndose a este tópico expresa lo siguiente: "Siendo la indemnización de perjuicios una consecuencia de la resolución o del cumplimiento del contrato que se dirige contra el contratante que por su culpa dejó incumplida su obligación, ella no puede obtenerse sin que previamente se declare la resolución del contrato. La resolución o el cumplimiento vienen a ser entonces la antesala de los perjuicios". En este mismo orden de ideas, en otro sitio, agrega que "la ley misma así lo señala en forma expresa en los preceptos que reglamentan la condición resolutoria subentendida. No es un derecho principal, sino accesorio. Siempre irá unido a la acción de resolución o de cumplimiento. Si se entabla como principal la acción deberá desecharse por falta de base jurídica”. Vío (1945), p. 290. 
De allí que dichas sentencias en la actualidad no puedan calificarse como aberrantes o desproporcionadas.

Ciertamente con anterioridad al año 1945 hubo fallos que abogaron por el carácter concurrente y complementario de la indemnización. Tal es el caso de la sentencia de18 de mayo de 1900 pronunciada por la Corte de Apelaciones de La Serena que denegó la indemnización exclusiva en el caso MacAuliffe y Compañía con Salinas, señalando en su considerando quinto, que del tenor literal del artículo 1489 fluye que

"la acción de perjuicios es accesoria de las de resolución o cumplimiento del contrato i por lo tanto no procede sino cuando se deduce juntamente con cualquiera de las otras dos" ${ }^{17}$.

Otro tanto se advierte a propósito de la sentencia de la Corte de Apelaciones de Valparaíso de 14 de mayo de 1910 en el caso Silva con Sociedad Lafrenz y Díaz, puesto que desechó la pretensión indemnizatoria, argumentando el tribunal que

"no es procedente la demanda de perjuicios cuando al propio tiempo no se pide el cumplimiento o resolución del contrato que se dice infringido, antecedente que, por lo demás, puede influir en la determinación de los perjuicios según sea el extremo por el que el demandante se decida" ${ }^{18}$.

Sin embargo, los postulados de Efraín Vío determinaron que la jurisprudencia se enfilara decididamente a desestimar la autonomía de la indemniza-

${ }^{17}$ En este caso Mac Auliffe y Cía. celebró con Marcos Salinas un contrato de compraventa de cal, por un período de tres años. El comprador se constituyó en mora y Auliffe demandó indemnización por inejecución. El juzgado de primera instancia acogió la demanda, invocando la fuerza obligatoria del contrato y la facultad del acreedor para acumular la indemnización moratoria a la indemnización compensatoria contenida en el numeral 3 del artículo 1553. Sin embargo, la Corte de Apelaciones de La Serena revocó dicha sentencia, citando el tenor literal del artículo 1489 y descartando la aplicación del artículo 1553, pues se trataba de un contrato bilateral y no de una obligación de hacer (véase sentencia Mac Auliffe con Salinas (1900), pp. 693-694).

${ }^{18}$ La cursiva es nuestra. En este caso Rómulo Silva celebró con la sociedad colectiva Lafrenz y Díaz un contrato de venta de doscientos bueyes. No obstante, el comprador se negó a recibir tales bueyes por no cumplir las condiciones estipuladas en el contrato frente a lo cual el vendedor solicitó al tribunal que condenara al comprador a indemnizarle los daños por incumplimiento del contrato, dado que tuvo que vender los bueyes al precio de plaza que era inferior al pactado. El tribunal desechó la demanda argumentando que no procede la indemnización si no se solicita la resolución o la pretensión de cumplimiento específico (véase sentencia Silva con Lafrenz y Díaz (1910), pp. 580-582.) 
ción, cualquiera fuera la obligación incumplida, y sostuviera que existe una relación de precedencia de la pretensión de cumplimiento específico o de la resolución respecto de la indemnización de daños, perfilando la indemnización como accesoria a tales acciones o remedios por incumplimiento, constituyendo esta una consecuencia de aquellas ${ }^{19}$. De hecho, las sentencias de nuestros tribunales han realizado constantes alusiones al carácter secundario ${ }^{20} \mathrm{o}$ accesorio de la indemnización ${ }^{21}$ y a la existencia de una relación indisoluble entre ésta y aquellos ${ }^{22}$.

${ }^{19}$ En tal sentido destaca la sentencia de la Corte de Apelaciones de Punta Arenas en Sociedad Pesquera Esmeralda con Cofrima S.A., que desestimó la acción resolutoria y la indemnización, indicando que del tenor del artículo 1489 aparece que ambas pretensiones están íntimamente ligadas, existiendo una "relación de precedencia de la acción resolutoria respecto de la indemnizatoria y de accesoriedad de ésta frente a la primera" (véase el considerando quinto de la sentencia Sociedad Pesquera Esmeralda con Cofrima S.A.(1990), pp. 43-47). En este caso Sociedad Pesquera Esmeralda S.A. requirió al tribunal que declarara la resolución del contrato celebrado con Cofrina S.A sobre trabajo conjunto de extracción de centollas en el litoral de la XII Región y la condenara a indemnizar los daños por inobservancia de la obligación de entregar a la demandante el 25\% del producto capturado. Sin embargo, la Corte resolvió que el contrato había expirado por el vencimiento del plazo, resultado improcedente la acción resolutoria y la indemnización.

${ }^{20}$ Otro tanto se aprecia en la sentencia pronunciada por la Corte Suprema ante el cumplimiento imperfecto de la obligación de entregar cueros lanares en Oviedo con Sociedad Agrícola Sacor Ltda., pues el tribunal señala que el cumplimiento o resolución del contrato a que alude el artículo 1489 son derechos principales, que se complementan con un derecho secundario, cual es obtener la indemnización de los daños que le ha causado la falta de cumplimiento total o parcial de la obligación" (véase el considerando séptimo de la sentencia Oviedo con Sociedad Agrícola Sarcor Ltda. (2008). Esta doctrina es reiterada por la Corte de Apelaciones de La Serena en el caso Fernández Chaparro con Méndez Maturana sobre incumplimiento de un contrato de promesa de venta, ya que señaló que la resolución o el cumplimiento específico a que alude el artículo $1489 \mathrm{del} C C$ son "derechos principales, que se complementan con un derecho secundario, cual es obtener la indemnización de los perjuicios sufridos" (véase considerando sexto de la sentencia Fernández Chaparro con Méndez Maturana (2010).

${ }^{21}$ Así se advierte en la sentencia de la Corte de Apelaciones de Chillán en Bustos con Betancourt, confirmada por la Corte Suprema, que sostiene que frente a la inejecución contractual no procede solicitar la indemnización sin pedir previamente la resolución o el cumplimiento del contrato, porque las acciones optativas del artículo 1489 llevan envuelta la indemnización de daños, pues estos no son accesorios del incumplimiento sino de dichas acciones optativas (véase el considerando tercero de la sentencia Bustos con Betancourt (2003). En igual sentido, destaca la sentencia de la Corte Suprema en Cataldo con Empresa Portuaria San Antonio, pues resolviendo la resolución del contrato de trabajo demandada, indica en su considerando décimo segundo que "la acción de indemnización de perjuicios es accesoria a la de resolución hecha valer, y debe, por su naturaleza, seguir la suerte de ésta, que constituye su antecedente jurídico necesario"(véase sentencia Cataldo con Empresa Portuaria San Antonio (2010). Otro tanto acontece en la sentencia de la Corte de Apelaciones de Temuco en el caso CoulonTopp con Fernández Briso sobre inejecución de un contrato de obra (véase sentencia CoulonTopp con Fernández Briso (2009).

${ }^{22}$ Tal es el caso de la sentencia de la Corte de Apelaciones de Valparaíso pronunciada en Muñoz Cerda con MassuMassu que desestimó la indemnización exclusiva a propósito de la inobservancia de la obligación de celebrar el contrato de compraventa definitivo 
Un razonamiento similar se advierte en nuestra doctrina tradicional ${ }^{23}$, pero, como lo indicamos en otro sitio $^{24}$, los autores que integran esta corriente de opinión no han sistematizado argumentos que permitan sustentar este planteamiento. No obstante, es posible inferir que las premisas en la que este se sustenta son la interpretación de la expresión "con indemnización de perjuicios" contenida en el inciso segundo del artículo 1489 del Código Civil en su acepción literal más frecuente; la resolución o el cumplimiento específico como fundamento de la indemnización por incumplimiento; la opción restringida y jerarquizada del acreedor para demandar en forma exclusiva las acciones o remedios contractuales a los contenidos en dicho Código y la ubicación del referido artículo 1489 en el título IV del libro III, relativo a las obligaciones condicionales.

Con todo, podría pensarse que la discusión en torno a la procedencia de la indemnización exclusiva solo tendría cabida a propósito de la inejecución de las obligaciones de dar, pero no tratándose de la de las obligaciones de hacer o no hacer, toda vez que en el primer supuesto falta una norma específica que faculte al acreedor para demandar en forma exclusiva la indemnización de daños ${ }^{25}$. Sin embargo, y como se abordará brevemente en el próximo apartado, durante décadas la Corte Suprema desestimó la autonomía de la indemnización, incluso tratándose de la inobservancia de las obligaciones de hacer, lo que resulta particularmen-

derivado de un contrato de promesa, pues no se entregó el inmueble prometido, aduciendo, en su considerando décimo séptimo, que para que el acreedor pueda intentar dicha acción "es requisito esencial que demande la resolución o el cumplimiento forzado del contrato, dado que la indemnización es una consecuencia de éstos, existiendo entre ella y aquéllos una relación indisoluble"(véase sentencia Muñoz Cerda con MassuMassu (2012).

${ }^{23}$ Cfr. Barcia (2008), p. 85; Vial (2007), pp. 239-240, Troncoso (2007), p. 141 y Arturo Alessandri en Alessandri-Somarriva-Vodanovic (2004), p. 259. En contra, Manuel Somarriva indica que el acreedor puede optar entre demandar el cumplimiento específico o la indemnización, toda vez que los artículos 1553 y 1555 del Código Civil así lo prevén a propósito del incumplimiento de las obligaciones de hacer y las obligaciones de no hacer, respectivamente. Precisa que a la misma conclusión debe arribarse en caso de inejecución de una obligación de dar, puesto que la opción del acreedor consagrada en el artículo 1553 no es excepcional sino "una aplicación de la regla general”. Agrega que en las obligaciones con cláusula penal, el artículo 1537 faculta al acreedor para escoger el cumplimiento de la obligación o la pena y ésta última es una indemnización convencional y anticipada (Alessandri-SOMARriva-VODANOVIC (2004), p. 259).

${ }^{24}$ Cfr. LóPEz (2010), pp. 71-85. Para un análisis más detallado véase LóPEz (2014a), pp. 38-54.

${ }^{25}$ La ausencia de una norma que permita al acreedor de una obligación de dar optar por la indemnización exclusiva ha sido el argumento para negar su procedencia autónoma tratándose del incumplimiento de estas obligaciones. En tal sentido, Manuel Somarriva en Alessandri-Somarriva-Vodanovic (2004), pp. 259-260; Peñailillo (2003), pp. 433-434; Fueyo (2004), pp. 347-348; Abeliuk (2010), p. 813 y Ramos (2008), pp. 239-242. En contra, Correa (1933), pp. 91-93; VidAL (2007), p. 527 y LóPez (2010), pp. 95-97. 
te sorprendente si se considera que el numeral tres del artículo 1553 del Código Civil permite al acreedor solicitarla directamente.

\section{La concurrencia y dependencia de la indemnización por incumplimiento de las obligaciones de dar}

Una revisión de la doctrina nacional evidencia que los argumentos que se han esgrimido para desconocer el ejercicio autónomo de la indemnización por inejecución de las obligaciones de dar y sustentar la relación de precedencia de la pretensión de cumplimiento específico o de la resolución respecto de la indemnización, no resultan del todo acertados ni irrefutables.

Así, nuestra doctrina ${ }^{26}$ ha argumentado que si el acreedor pudiese optar por la indemnización, la obligación se transformaría en alternativa, en circunstancias que dicha obligación no constituye la regla general y requiere norma expresa. Por otra parte, ha argüido que legislador en el artículo 1537 del Código Civil, excepcionalmente ha otorgado al acreedor de las obligaciones de dar el derecho de optar por la indemnización en la cláusula penal, lo que confirma que la regla general es que dicha opción no procede. Asimismo, ha indicado que el artículo 1672 del referido Código faculta al acreedor a demandar el precio, en el evento de que la cosa se 148 destruya por culpa del deudor, lo que evidenciaría que lo que debe pedirse es el cumplimiento de la obligación. Por último, se ha señalado que si se admitiera que el acreedor demande la sola indemnización se infringiría el principio de la fuerza obligatoria, el principio de conservación de los actos jurídicos y el principio de identidad del pago.

A partir de estos argumentos, nuestros tribunales desestimaron en forma sistemática la indemnización exclusiva por incumplimiento de una obligación de dar en el período comprendido entre el 18 de mayo de 1900 y el 30 de octubre de 2012, denegando la tutela resarcitoria que era pro-

${ }^{26}$ En tal sentido Arturo Alessandri en Alessandri-Somarriva-Vodanovic (2004), p. 259; Fueyo (2004), pp. 353 y 354; Abeliuk (2010), p. 813 p. 672 y Ramos (2008), pp. 239 242. En contra, Guillermo Correa sostiene que no es acertado el argumento según el cual la obligación deviene en alternativa, dado que esta nace con dos o más objetos debidos, caso en el cual la facultad de optar surge como un derecho, a diferencia de lo que sucede cuando el acreedor puede escoger entre uno u otro medio de tutela, pues tal facultad nace como consecuencia de la inejecución contractual. Agrega que de conformidad al artículo 1500 inciso segundo del Código Civil, la facultad de optar en las obligaciones alternativas corresponde al deudor, a menos que se haya pactado lo contrario, lo que no ocurre en el caso que se viene comentando, ya que la opción es del acreedor, cfr. Correa (1933), pp. 91-93. Por otra parte, como indica Âlvaro Vidal, el artículo 1672 no establece la primacía del cumplimiento específico, sino que le priva de este remedio en razón de la objetiva imposibilidad, reconociéndole como única opción la indemnización de daños, cfr. VIDAL (2007), p. 527. 
cedente y ocasionado la insatisfacción del interés del acreedor. Sirva de ejemplo la sentencia pronunciada el 14 de mayo de 1910 por la Corte de Apelaciones de Valparaíso en Silva con Sociedad Lafrenz y Díaz a propósito del cumplimiento imperfecto de la obligación de entregar doscientos bueyes, pues el tribunal desechó la pretensión indemnizatoria, argumentando que el cumplimiento o la resolución del contrato constituyen el antecedentede la indemnización ${ }^{27}$.

Un fenómeno similar acontece con la sentencia de la Corte Suprema de 27 de enero de 1993 en el caso Resinas y Terpenos Ltda. con Cía. de Acero del Pacífico S.A., toda vez que el tribunal desestimó la indemnización por inejeución de un contrato de venta de acciones, indicando que los daños que se cobran son "una consecuencia directa e inmediata del incumplimiento contractual que se demanda" y que como no se dio lugar a la acción resolutoria no procede tampoco acoger la pretensión indemnizatoria ${ }^{28}$.

Otro tanto se advierte en la sentencia de 3 de marzo de 2008 de la Corte de Apelaciones de la Serena en Aranda con Major Drilling Chile S.A. ${ }^{29}$, en que el tribunal declaró que no resulta procedente demandar indemnización frente al incumplimiento de un contrato de suministro, sin que se haya ejercitado alguna de las dos acciones optativas a que se refiere el artículo 1489 del Código Civil, ya que "ellas son el antecedente jurídico de donde arranca la acción indemnizatoria". Precisa así que dicha acción carece de todo basamento legal y por ello debe ser desestimada, dado que falta tal requisito de admisibilidad.

En el mismo sentido destaca la sentencia de la Corte Suprema de 22 de septiembre de 2008 ante el cumplimiento imperfecto de la obligación de entregar cueros lanares en el caso Oviedo con Sociedad Agrícola Sacor Ltda., pues el tribunal señala que el cumplimiento o resolución del contrato a que alude el artículo 1489 son derechos principales, que se complementan

${ }^{27}$ Véase n. 18.

${ }^{28}$ Véase considerando sexto de la sentencia Sociedad Resinas y Terpenos Ltda. con Cía. de Aceros del Pacífico S.A. (1993). En este caso Sociedad Resinas y Terpenos Ltda. demandó a Cía. de Aceros del Pacífico S.A. y solicitó al tribunal la resolución del contrato de venta de acciones de la Sociedad Constructora de Establecimientos Hospitalarios S.A. e indemnización de daños, pues no le entregó tales acciones. Dicho tribunal acogió la demanda, pero el tribunal de segunda instancia y la Corte Suprema la desestimaron.

${ }^{29}$ Los hechos fueron los siguientes: Confecciones Taller Imagen Ltda. entabló acción de indemnización de daños contra Major Drilling Chile S.A por inejecución de un contrato de suministro y consignación de prendas de vestir, pues la demandada comenzó a incumplir el contrato y decidió adquirir tales prendas a la competencia, en circunstancias que existía cláusula de exclusividad. Sin embargo, el tribunal de primera instancia no acogió la demanda, decisión que confirmó la Corte de Apelaciones conociendo del recurso de apelación interpuesto (véase sentencia Aranda con Major Drilling Chile S.A. (2008). 
con el derecho secundario de obtener la indemnización de los daños que le ha causado la falta de cumplimiento de la obligación ${ }^{30}$.

Lo cierto es que no resulta convincente negar al acreedor de una obligación de dar el derecho a optar en favor de la indemnización de daños invocando la ausencia de una norma general que le reconozca tal derecho, no solo porque este razonamiento contraviene el principio de reparación integral de la indemnización y desconoce la libre opción del acreedor y el verdadero fundamento de la indemnización de daños ${ }^{31}$, sino porque además no existe ninguna razón que justifique que ella solo proceda para la inejecución de las obligaciones de hacer y no hacer ${ }^{32}$. En efecto, donde existe la misma razón debe existir la misma disposición ${ }^{33}$.

${ }^{30}$ En este caso Industrias Magromer, empresa argentina, demandó a la sociedad Sarcor, empresa chilena, por los daños derivados del cumplimiento parcial de su obligación de entregar ciento cincuenta mil cueros lanares, pues solo entregó sesenta y un mil a Sarcor y el resto a otros compradores, lo que redundó en la inejecución del resto del contrato. En tal sentido argumentó que no existían más proveedores que pudieran cubrir el saldo de producción no entregado por Sarcor y que como la obligación era de especie o cuerpo cierto resultaba aplicable el artículo 1672 del Código Civil, en virtud del cual la obligación del deudor subsiste, pero varía de objeto, ya que es obligado al precio de la cosa y a indemnizar al acreedor. El tribunal de primera instancia rechazó la demanda, 150 sentencia que fue confirmada por la Corte de Apelaciones de Punta Arenas, que indicó en su considerando quinto: "La acción de indemnización que ha sido presentada por el demandante, es la que emana de la responsabilidad contractual -incumplimiento de un contrato-y, por tanto, debió solicitar o la resolución de dicho contrato, más la respectiva indemnización lo que no hizo en el caso de autos, en que simplemente dedujo la acción indemnizatoria en forma independiente, sin solicitar ninguno de los derechos alternativos reseñados", véase sentencia Industria Magromer Cueros y Pieles S.A. con Sociedad Agrícola Sacor Ltda. (2007). Este razonamiento es reiterado por la Corte Suprema, véase sentencia Oviedo con Sociedad Agrícola Sarcor Ltda. (2008).

${ }^{31}$ Cfr. López (2010), pp. 93-103.

${ }^{32}$ En nuestra doctrina la opción exclusiva en favor de la indemnización por inobservancia a las obligaciones de dar se advierte en Luis Claro Solar tratándose de las obligaciones genéricas, pues postula que el legislador, frente a la inejecución de obligaciones de dar individuos de género determinado, reconoce al acreedor la facultad de procurarse en el mercado otras cosas a expensas del deudor o bien, demandar la indemnización que represente la diferencia entre el precio de la compra y el curso de los objetos adquiridos el día fijado para la entrega, cfr. Claro Solar (1937), p. 556. Manuel Somarriva, por su parte, aboga por dicha opción en razón de los argumentos indicados en la n. 23 de este artículo. Por su parte, Álvaro Vidal admite la opción entre el cumplimiento específico y la indemnización atendida la falta de norma expresa que establezca una prelación entre ambas, el hecho que la objetiva posibilidad de la prestación no garantiza al acreedor la satisfacción de su interés específico y la circunstancia que la opción de cumplir in natura pertenece al deudor y el acreedor puede escoger entre diversos remedios contractuales, cfr. VIDAL (2006b), p. 527.

${ }^{33}$ La Corte Suprema colombiana ha reconocido la autonomía de la indemnización por incumplimiento de obligaciones de dar, invocando precisamente este argumento. Así, 
Es más, a través de un ejercicio de interpretación de determinadas normas contenidas en el Código Civil relativas al incumplimiento de una obligación de dar, se puede arribar a la conclusión de que el legislador faculta al acreedor para optar por la indemnización exclusiva. En efecto, el inciso segundo del artículo 1590 admite tal opción en caso de ejecución imperfecta de una obligación de dar, opción que también consagra el artículo 1814 en el evento que falte una parte considerable de la cosa vendida al tiempo de perfeccionarse el contrato de compraventa y el artículo 1537 en el supuesto que se pacte una cláusula penal para garantizar el cumplimiento de una obligación de dar.

Por otra parte, hay que considerar que la opción en favor de un medio de tutela es un derecho del acreedor y que el artículo 12 del Código Civil dispone que podrán renunciarse los derechos conferidos por las leyes con tal que miren al interés individual del renunciante y no esté prohibida su renuncia. Pues bien, no existe norma en dicho Código que prohíba al acreedor de una obligación de dar renunciar a su derecho de optar por el cumplimiento específico o la resolución. Asimismo, el legislador no ha prohibido interponer la acción indemnizatoria en forma autónoma tratándose del incumplimiento de una obligación de dar y sabido es que en el Derecho Privado puede hacerse todo aquello que el legislador no prohíbe ${ }^{34}$.

Probablemente recogiendo los argumentos esgrimidos por alguna doctrina nacional entre los años 2006 y $2012^{35}$ y por las sentencias pronunciadas durante esa época que admitían la indemnización de daños exclusiva por inejecución de una obligación de hacer ${ }^{36}$, la Corte Suprema resolvió admitir la pretensión indemnizatoria autónoma por inobservancia de una obligación de dar en el caso Zorín con Siderúrgica Huachipato S.A. ${ }^{37}$, zanjando así la clásica discusión en torno a su procedencia respecto de esta clase de obligaciones.

ha sostenido: “¿Por qué ese supuesto tratamiento discriminatorio, desde todo punto de vista inadmisible? Donde hay la misma razón debe haber siempre la misma disposición. En cuanto toca con sus efectos, las obligaciones no son de mejor o peor categoría", véase sentencia Claudio MoronMoscote con Conservas California S.A. (1977), p. 327.

${ }^{34}$ Así se ha pronunciado la Corte Suprema en aquellas sentencias en que ha admitido la autonomía de la indemnización, véanse las sentencias: Agroindustria San Vicente S.A. con Exportadora Aconcagua Ltda. (2009), Opazo Lamana con Inmunomédica Ltda. (2010), Asociación de Productores de Huevos de Chile con Banco de Chile (2011), Toro Fuentealba con Concha Sandoval (2012) y Reyes Valdivia con Escuela de Tripulantes y Portuaria (2012).

${ }^{35}$ Véase Pizarro (2007a), p. 216 y él mismo (2007b), p. 153; Barros (2008), p. 409, De la Maza (2007), pp. 164-165, Corral (2010), pp. 232-233, LóPez (2010), pp. 85-103; Vidal (2010), pp. 777-778, Alcalde (2012), p. 58 y Elorriaga (2012), pp. 1375-1376.

${ }^{36}$ Véase infra II.1. i)-vi).

${ }^{37}$ Sobre los hechos constitutivos de este caso véase infra II.1. vii. 
Sin embargo, la sentencia pronunciada por la Corte Suprema el 30 de octubre de 2013 con ocasión del caso Cuadra Calderón con Céspedes Arteagabeitía evidencia un aparente vuelco en el razonamiento de nuestro máximo tribunal, dado que a diferencia de los tribunales de instancia, desestimó la autonomía de la indemnización, pues consideró que la obligación incumplida, consistente en ceder y transferir al demandante los derechos que le pertenecían en la sociedad comercial Colegio San Agustín Ltda., es una obligación de dar y no de hacer, precisando que las partes invocaron el artículo 1553 del Código Civil, en circunstancias que resultaba aplicable el artículo 1489 que constituye un estatuto jurídico distinto ${ }^{38}$.

La interrogante que surge entonces es, ċuál sería la diferencia entre el estatuto establecido por el artículo 1553 y el artículo 1489 tratándose de la indemnización de daños? ¿El primero admitiría en forma expresa la procedencia de la indemnización exclusiva en su numeral tres y el segundo no contemplaría esa posibilidad? Aun cuando nuestro máximo tribunal no afirme que esa sea la diferencia, es posible inferirla, toda vez que si estimara que en ambos casos procede la indemnización autónoma la habría acogido, precisado tan solo el error en la invocación de la norma que resultaba pertinente, pero no la habría desestimado indicado que el régimen que ellas establecen es diverso.

152 Un razonamiento similar se advierte en la sentencia pronunciada por la Corte de Apelaciones de Santiago el 12 de septiembre de 2013 en el caso Laboratorio de Control Técnico con Celestron Ltda., pues tampoco acoge la indemnización exclusiva, aduciendo que el tenor literal del artículo 1489, en circunstancias que la demandada vendió al actor un equipo defectuoso, encargándosele su reparación en un plazo determinado que no efectuó correctamente, causándole daño emergente y un lucro cesante considerable $^{39}$. Lo sorprendente es que el tribunal justifica su decisión, invocando premisas que a esa época ya habían sido superadas por la Corte Suprema.

${ }^{38}$ Consúltese la sentencia Cuadra Calderón con Céspedes Arteagabeitía (2013). Cabe señalar que el tribunal de primera y segunda instancia acogieron la indemnización exclusiva, pero invocando el tenor del numeral 3 del art. 1553 del CC. La Corte Suprema no se pronunció respecto de la admisibilidad de la indemnización autónoma tratándose de las obligaciones de dar, sino solo se limitó a señalar en su considerando noveno que no debería haberse invocado el artículo 1553 y que el "fundamento de la demanda carece de sustento jurídico". A continuación aludió, en su considerando décimo, al principio de pasividad y el principio de congruencia procesal que estatuye que los fallos no pueden pronunciarse sobre puntos no formulados en el pleito, precisando que procede rechazar la pretensión indemnizatoria, porque se invocó un precepto errado para justificar su procedencia.

${ }^{39}$ Véanse considerandos vigésimo octavo y noveno de la sentencia Laboratorios Control Técnico LlayLlay Ltda. y Celestron Ltda. (2011). 
Así, en su considerando sexto expresa lo siguiente:

"Que de lo anterior, se desprende que ante el incumplimiento de uno de los contratantes, el otro tiene derecho de pedir la resolución o el cumplimiento del contrato, y en su caso, como un derecho secundario, la compensación de los daños que el incumplimiento total o parcial le haya ocasionado".

La jurisprudencia así lo ha reconocido, al señalar:

"La obligación de indemnizar nace como consecuencia del incumplimiento o cumplimiento imperfecto o tardío de aquello a que el deudor se obligó, pero solo se entiende si se ha declarado, a su vez, la resolución del contrato o se ha dispuesto su cumplimiento" ${ }^{40}$.

En contra de esta decisión Laboratorios Llay Llay interpuso un recurso de casación en el fondo por infracción de lo dispuesto en el artículo 1489 , aduciendo que este precepto admite que el acreedor demande la indemnización exclusiva, citando sentencias anteriores de la Corte $\mathrm{Su}$ prema que así lo han reconocido. Sin embargo, dicho tribunal acogió el referido recurso y concedió la indemnización autónoma al demandante, pero curiosamente sostuvo que la obligación incumplida era de hacer, en circunstancias que era de hacer y de dar. Con todo, no reparó que, de acuerdo con lo resuelto en Cuadra Calderón con Céspedes Arteagabeitía, no podría haberla concedido si el estatuto jurídico que se denunciaba infringido era el artículo 1489 y no el artículo 1553 del Código Civil.

Por cierto, a partir de esta diversa calificación de la prestación ejecutada imperfectamente podría sostenerse que aún se mantiene la incertidumbre respecto de la procedencia de la indemnización de daños autónoma por incumplimiento de una obligación de dar, pero un detenido análisis de este caso $^{41}$ nos permitirá constatar que, en realidad, poco a poco, ella comienza a disiparse.

\section{La concurrencia y dependencia de la indemnización} por incumplimiento de las obligaciones de hacer

Una lectura del numeral tres de artículo 1553 de nuestro Código Civilnos lleva a la irrefutable conclusión que tratándose de la inejecución de una

${ }^{40}$ Véase sentencia de la Corte de Apelaciones Laboratorios Control Técnico con Celestron Ltda. (2013), pp. 146-147

${ }^{41}$ Véase infra. II, 1, xii. 
obligación de hacer el acreedor está facultado para demandar la indemnización exclusiva. Dicho numeral es claro: el acreedor podrá solicitar que el deudor "le indemnice de los perjuicios resultantes de la infracción del contrato".

Lo cierto es que, contrariamente a lo que pudiera pensarse, un examen de nuestra jurisprudencia revela que durante algunas décadas, esta prescindió del tenor de dicho numeral y desestimó la pretensión indemnizatoria por incumplimiento de obligaciones de hacer, distanciándose de la correcta doctrina sentada en los casosBarrios con Rozé, Barthet con Paine y Virgilio y otros con Schiavetti y Hermanos, a los que nos hemos referido precedentemente ${ }^{42}$.

Sirva como ejemplo la sentencia de la Corte Suprema dictada en el caso Warncken con Ferrer de 28 de julio de 1933 en que pronunciándose sobre la inejecución de la obligación de administrar un fundo, desestimó el artículo 1553 del Código Civil, indicando que el artículo 1489 consagra la indemnización como "una consecuencia de la resolución del contrato", de modo que no puede demandarse en forma exclusiva, pues en tal caso la acción de daños quedaría sin "el respectivo antecedente jurídico que debe fundamentar toda acción" "43. Este fallo fue acordado con el voto disidente de los ministros Mariano Fontecilla, Gregorio Schepeler y Al-

154 fredo Rondanelli, quienes tampoco aludieron a dicho precepto, sino que refiriéndose al artículo 1489, señalaron que dicha disposición rige un caso especial que no enerva el general, agregando:

"para instaurar acción de indemnización de perjuicios por inejecución de un contrato basta que se haya causado al demandante y que la inejecución sea imputable al demandado; pero no es condición sine qua non pedir previa o simultáneamente la ejecución del contrato o su resolución, bastando los indicados, como fundamentos jurídicos de la acción"44.

Un fenómeno similar se advierte en la sentencia de la Corte de Apelaciones de Temuco en el caso Coulon Topp con Fernández Briso sobre incumplimiento de un contrato de ejecución de obra, pues omite cualquier referencia al artículo 1553 e indica en su considerando primero, lo siguiente:

${ }^{42}$ Véase supra n. 10-12.

${ }^{43}$ Véase considerando cuarto y quinto de la sentencia Warncken con Ferrer (1933), pp. 495-501.

${ }^{44}$ Véase la sentencia Warncken con Ferrer (1933), pp. 500-501. 
"es de parecer que para cobrar perjuicios originados por el incumplimiento de las obligaciones nacidas de un contrato bilateral, se hace necesario, como requisito indispensable, que esta acción se ejerza como accesoria de la acción destinada a pedir el cumplimiento de la misma, o de aquella en que se solicite la resolución. Así se desprende de la propia redacción del artículo 1489 del Código Civil $[\ldots] " .45$.

Esta argumentación es reiterada por la Corte de Apelaciones de La Serena en el caso Fernández Chaparro con Méndez Maturana sobre inejecución de un contrato de promesa de venta, toda vez que señaló que la resolución o la pretensión de cumplimiento específico a que alude el referido artículo 1489 son "derechos principales, que se complementan con un derecho secundario, cual es obtener la indemnización de los perjuicios sufridos" $"$.

Otro tanto acontece en la sentencia pronunciada por la Corte de Apelaciones de Valparaíso el 1 de junio de 2011 en el caso Segovia Barrientos con Sáez Arroyo, confirmada por la Corte Suprema, a propósito del incumplimiento de la obligación de entregar un inmueble, derivada de un contrato de compraventa. En efecto, dicho tribunal señaló que no

${ }^{45}$ Cfr. sentencia Coulon Topp con Fernández Briso (2009). Doña Madeleine Coulon Topp demandó el cumplimiento de un contrato de ejecución de obra material con indemnización de daños en contra de Marco Fernández Briso. En virtud de dicho contratola demandante le encargó la dirección, administración y ejecución de los trabajos de desarme, construcción y remodelación de una vivienda de su propiedad. Sin embargo, esta no entregó el permiso de construcción para iniciar las obras ni proporcionó las condiciones adecuadas para su inicio. El tribunal de instancia acogió la pretensión de cumplimiento y la indemnización por concepto del saldo de precio y daño emergente correspondiente a los trabajos adicionales que la demandada tuvo que efectuar. Asimismo, desestimó la pretensión indemnizatoria del demandado indicando que del artículo 1489 se infiere que la indemnización es accesoria a las acciones de cumplimiento y resolución, de modo que no puede demandarse la indemnización en forma independiente, pues quedaría sin el antecedente que debe fundar toda acción, véase sentencia del Primer Juzgado Civil de Temuco Coulon Topp con Fernández Briso (2009).

${ }^{46}$ Véase el considerando sexto de la sentencia Fernández Chaparro con Méndez Maturana (2010). En este caso Jorge Fernández Chaparro interpuso demanda de indemnización de daños por inejecución de un contrato de promesa de venta de un inmueble en contra de Christian Méndez Maturana, pues aun cuando el demandante pagó el precio del referido inmueble, el demandado no le entregó el inmueble ni suscribió el contrato prometido. El demandado indicó que celebró un contrato de promesa de venta, pero no recibió el precio del promitente comprador, solicitando en forma reconvencional la resolución del contrato con indemnización por dicho incumplimiento. El tribunal de primera instancia desestimó la pretensión indemnizatoria, sentencia que fue confirmada en segunda instancia, indicando que esta es secundaria respecto de la resolución, de modo que la demandante debió solicitar la resolución como derecho principal. 
es procedente intentar una acción indemnizatoria, invocando el artículo 1489 desvinculado del antecedente jurídico que la sustenta, ya que ello contraviene los principios de buena fe, equidad y economía procesal e, incluso, constituye una especie de abuso del derecho, al tratar de implementar una norma completamente distinta al espíritu de aquella ${ }^{47}$.

El último caso al que nos referiremos es Muñoz Cerda con Massu Massu resuelto por la Corte de Apelaciones de Valparaíso el 8 de agosto de 2012 con ocasión de la inejecución de la obligación de celebrar el contrato de compraventa definitivo derivado de un contrato de promesa. En esta ocasión, al igual que en las que hemos venido comentando, se desestimó la indemnización exclusiva, aduciendo el tribunal que para que el acreedor pueda intentar dicha acción

"es requisito esencial que demande la resolución o el cumplimiento forzado del contrato, dado que la indemnización es una consecuencia de éstos, existiendo entre ella y aquéllos una relación indisoluble"

y precisando que este "ha sido el criterio mayoritario de nuestra jurisprudencia" ${ }^{" 48}$.

${ }^{47}$ Confróntese el considerando sexto de la sentencia Segovia Barrientos y Saez Arroyo (2011). Ester Verónica y Marcela Isabel, ambas de apellidos Segovia Barrientos, interpusieron una demanda de indemnización en contra Claudio Sáez Arroyo por inejecución de la obligación de entregar un inmueble derivada de un contrato de compraventa. El tribunal de instancia rechazó la pretensión indemnizatoria de las demandadas, precisando que los daños a los que alude el artículo 1489 son accesorios, véase sentencia Segovia Barrientos y Saez Arroyo del Primer Juzgado Civil de Valparaíso (2010). La demandante dedujo un recurso de apelación ante la Corte de Apelaciones de Valparaíso que confirmó el fallo apelado, lo que determinó que interpusiera recurso de casación en el fondo por infracción de los artículos 1826 y 1489, invocando el carácter autónomo de la indemnización. La Corte Suprema rechazó tal recurso aduciendo que la pretendida violación de los artículos 13 y 19 no pueden servir de base para un recurso de casación en el fondo, puesto que ellos constituyen principios de orden general y que el demandante debería haber invocado el artículo 1553 y acreditado el daño que reclama, véase sentencia Segovia Barrientos con Arroyo López (2012).

${ }^{48}$ Véase considerando séptimo de la sentencia de Muñoz Cerda con Massu Massu (2012). William Muñoz Cerda interpuso en contra de Ana y Teresa, ambas de apellido Massu, una demanda de indemnización por incumplimiento de la obligación de celebrar el contrato de compraventa definitivo derivado de un contrato de promesa, invocando el numeral 3 del artículo 1553, pues no le entregaron el inmueble prometido. Ellas, a su vez, citando el mismo precepto legal, demandaron reconvencionalmente indemnización por inejecución de la obligación del promitente comprador de firmar el contrato de compraventa definitiva. El tribunal de primera instancia rechazó la demanda principal y acogió la reconvencional. Frente a esta resolución William Muñoz deduce recurso de apelación ante la Corte de Apelaciones de Valparaíso, desestimando dicho tribunal su 
Sin embargo, la ministra María Angélica Repetto previno que no compartía los fundamentos esgrimidos para desestimar la pretensión indemnizatoria, toda vez que a la luz de lo dispuesto en el artículo $1553 \mathrm{~N}^{\circ}$ 3 es posible demandar la indemnización compensatoria sin necesidad que vaya aparejada a la petición de cumplimiento o resolución del contrato, citando las sentencias pronunciadas por la Corte Suprema en los casos Transportes Aeropuerto Express Limitada con LADECO S.A. de $2007^{49}$ y Oviedo con Sociedad Agrícola Sacor Ltda. de $2008^{50}$.

A nuestro juicio la Ministra está en lo correcto, por dos razones.

- En primer lugar, el tenor del artículo es claro. La única discusión que podría suscitarse es si el numeral tres de este precepto alude a una variante del cumplimiento específico o a la pretensión indemnizatoria ${ }^{51}$, pero esa interrogante el tribunal no se la plantea.

- En segundo lugar, a la fecha de dictación de dicha sentencia la Corte Suprema había admitido en forma reiterada la procedencia de la indemnización de daños por incumplimiento de una obligación de hacer.

Así lo revelan no solo las sentencias referidas por la Ministra sino, también, aquellas pronunciadas por la Corte de Apelaciones de Concepción en Faúndez Mora con Compañía de Telecomunicaciones de Chile S.A. el 29 de Marzo de $2011^{52}$ y por la Corte Suprema en Opazo Lamana con Inmunomédica Laboratorio Ltda. de 7 de diciembre de $2010^{53}$, Asociación de Productores de Huevos de Chile con Banco de Chile de 31 de agosto de $2011^{54}$ y Reyes Valdivia con Escuela de Tripulantes y Portuaria de 10 de julio de $2012^{55}$, cuyo análisis se abordará más adelante.

En efecto, en todas ellas el máximo tribunal sostuvo que la frase "cualquiera de estas tres cosas, a elección suya" contenida en el artículo 1553, da a entender claramente que la indemnización de daños "es concebible

pretensión indemnizatoria e indicando que confunde el objeto de contrato de promesa con el objeto del contrato prometido, pues no se reclama la inejecución de la obligación de suscribir el contrato, sino la entrega o tradición de la cosa, lo que determina la inaplicabilidad del artículo $1553 \mathrm{~N}^{\circ} 3$ y la procedencia del artículo 1489 , pues se trata de una obligación de dar, véase sentencia de Muñoz Cerda con Massu Massu (2012).

${ }^{49}$ Véase sentencia Transportes Aeropuerto Express Ltda. con LADECO S.A. (2007).

${ }^{50}$ Véase el considerando séptimo de la sentencia Oviedo con Sociedad Agrícola Sacor Ltda. (2008).

${ }^{51}$ En lo que concierne a esta discusión véanse n. 63-65.

${ }^{52}$ Véase sentencia Faúndez Mora con Compañía de Telecomunicaciones de Chile S.A. (2011).

${ }^{53}$ Véase sentencia Opazo Lamana con Inmunomédica Laboratorio Ltda. (2010).

${ }^{54}$ Véase sentencia Asociación de Productores de Huevos de Chile con Banco de Chile (2011).

${ }^{55}$ Véase sentencia Reyes Valdivia con Escuela de Tripulantes y Portuaria (2012). 
como solicitud autónoma, sin necesidad de ir aparejada a la petición de cumplimiento o de resolución del contrato de que esa obligación incumplida emanó". Así también lo evidencian las sentencias pronunciadas en Fisco de Chile con Sociedad Ingeniería y Construcción del Sur S.A. de 20 de noviembre de $2012^{56}$, Ampuero con Castillo de 28 de enero de $2013^{57}$, Steffen con Fundación Mi Casa de 10 de septiembre de $2013^{58}$ y Stange con Ripley Puerto Montt de 2 de octubre de $2013^{59}$.

\section{EL NUEVO PARADIGMA:}

LA INDEMNIZACIÓN DE DAÑOS COMO ACCIÓN O REMEDIO

POR INCUMPLIMIENTO CONTRACTUAL AUTÓNOMO, EXCLUSIVO O DIRECTO

Desde hace algunos años nuestra doctrina ha postulado la procedencia de la indemnización autónoma, directa o exclusiva por inejecución contractual, invocando diversos argumentos, tales como el libre derecho de opción del acreedor entre las acciones o remedios contractuales, la reparación integral del daño, la interpretación lógica y sistemática del artículo 1489 del Código Civil chileno y el carácter principal de la obligación de indemnizar ${ }^{60}$.

158 Dicha argumentación ha sido acogida expresamente en sentencias de reciente data por nuestra Corte Suprema ${ }^{61}$, incluso tratándose del incumplimiento de obligaciones de dar, superando así los inconvenientes que acarreaba la corriente de pensamiento según la cual la indemnización

${ }^{56}$ Véase sentencia Sociedad Ingeniería y Construcción del Sur S.A. con Fisco de Chile (2012).

${ }^{57}$ Véase sentencia Ampuero Ascencio con Castillo Hernández (2013).

${ }^{58}$ Véase sentencia Steffen Cáceres con Fundación Mi Casa (2013).

${ }^{59}$ Véase sentencia Stange con Ripley Puerto Montt (2013).

${ }^{60}$ Cfr. Pizarro (2007a), pp. 215-217 y él mismo (2007 b), pp. 151-153; Barros (2008), p. 409; LÓPEz (2010), pp. 88-97 y 99-113; VidAl (2011), pp. 771-778 y ElORRIAGa (2012), pp. 1374 y 1376. Otros autores solo la han admitido. Así, De LA MAZA (2007), pp. 164-165; Corral (2010), 232-233; Alcalde (2012), p. 58 y Contardo (2014), pp. 262-263.

${ }^{61}$ En lo que concierne a la libre opción del acreedor, la interpretación lógica de las disposiciones del Código Civil chileno y la reparación integral del acreedor véanse el considerando cuarto de la sentencia Faúndez Mora con Compañía de Telecomunicaciones de Chile S.A. (2011), décimo cuarto y décimo sexto la sentencia Opazo Lamana con Inmunomédica Laboratorio Ltda. (2010), séptimo de la sentencia Asociación de Productores de Huevos de Chile con Banco de Chile (2011), cuarto de la sentencia Reyes Valdivia con Escuela de Tripulantes y Portuaria (2012), vigésimo de la sentencia Ampuero Ascencio con Castillo Hernández (2013), décimo octavo de la sentencia Steffen Cáceres con Fundación Mi Casa (2013) y décimo noveno de la sentencia Stange Hoffman con Ripley Puerto Montt (2013), y curo, quinto y sexto de 1 sentencia Laboratorios Control técnico Llay Llay Ltda. con Celestron Ltda. (2014) 
de daños por inejecución contractual solo podía demandarse en forma concurrente, complementaria y accesoria al cumplimiento específico o a la resolución del contrato. Así, este nuevo razonamiento no restringe el derecho de opción del acreedor ni obsta a la desestimación de la tutela resarcitoria y evita que la CVCIM resulte inaplicable en aquellos casos que el acreedor demande la indemnización de daños como acción o remedio contractual autónomo, invocando los artículos 45.1 letra b.) y 61.1 letra b. ${ }^{62}$. Con todo, podría pensarse, como lo ha sostenido alguna doctrina, que los supuestos en que se presentaría la autonomía de la indemnización serían escasos, pues la indemnización (id quod interest) no sería distinta del valor de la prestación (aestimatio rei) ${ }^{63}$, sino un cumplimiento por equivalencia $^{64}$. Siguiendo este razonamiento, la indemnización de daños solo estaría constreñida a aquellos daños que exceden el valor de la prestación, restringiéndose así los supuestos en que se presentaría genuinamente como una acción o remedio autónomo o independiente ${ }^{65}$.

Sin embargo, a nuestro juicio, existen al menos tres argumentos para sostener que la indemnización comprende el valor de la prestación (daño intrínseco) y los daños que exceden dicho valor (daño extrínseco $)^{66}$. En primer

${ }^{62}$ Para un análisis más detallado de estos inconvenientes o problemas véase LóPEZ (2014a), pp. 55-70.

${ }^{63}$ Efectuando esta distinción en la doctrina comparada, entre otros, REMY-CoRLAY (2005), pp. 17 y 27-35; DíEz-PicAzo Giménez (1996), pp. 388 y 389, en especial n. 51; Castilla (2001), pp. 269-270 y Lamarca (2001), p. 147. Entre nosotros, Baraona (1997), p. 159 y ss.; Bustamante (2005), pp. 105-126; Corral (2010), p. 141 y ss.; Peñallillo (2009), pp. 334-338 y CONTARdo (2014), pp. 265-268.

${ }^{64}$ Cfr. Gatica (1959), p. 11 y ss.; Fueyo (2004), pp. 342-343, Meza (2007), p. 119 y Abeliuk (2008), pp. 810-811.

${ }^{65}$ Así, Juan Ignacio Contardo a propósito del caso Steffen con Fundación Mi Casa (2013) indica que, si bien el acreedor demanda a título de daños el costo de reparación del inmueble incendiado y las rentas impagas, en realidad está solicitando el cumplimiento a través de una forma particular, cual es, la reparación del objeto y el pago de las rentas, cfr. Contardo (2014), pp. 266-268. Precisa que existirán algunos casos en que la pretensión indemnizatoria podrá ejercerse de forma autónoma, pero para determinar cuáles son estos deberá analizarse si la pretensión tiene un contenido indemnizatorio real.

${ }^{66}$ La distinción entre daño intrínseco y daño extrínseco encuentra su origen en el Derecho Romano, específicamente en el Digesto 19, 1, 21, 3 de Paulo, pues en este pasaje distingue el interesse circa rem o intrinsecum y el interesse extra rem o extrinsecus. En efecto, señala: "Cum per vendito rem steterit, quo minus rem tradat, omnis utilitas emptoris in aestimationem venit, quae modo circa ipsam rem consistit: neque enim si potuit ex vino puta negotiari el lucrumfacere, id aestimandum est, non magit quam si trtiticum emerit et ob ea rem, quod nom sit traditum, familia eius fame laboraverit: nam premium tritici, non sevorum fame necatorum consequitur". Posteriormente, Robert Pothier acuñará esta distinción, indicando que los daños intrínsecos son aquellos que puede sufrir el acreedor con respecto a la misma cosa objeto de la obligación, sin considerar los que por otro motivo no ha experimentado en sus otros bienes, cfr. Pothier (1839), p. 95. 
lugar, estimamos que la distinción que realizan los preceptos de nuestro Código Civil entre el precio de la cosa y los daños por incumplimiento no es concluyente, pues el artículo 1678 considera dicho precio como daño ${ }^{67}$. Por otro lado, el equivalente pecuniario constituye una manifestación de la tutela resarcitoria, dado que, al igual que la indemnización de daños, pretende dejar al acreedor en la misma situación que se encontraría si el contrato se hubiera cumplido en la forma acordada por las partes, al menos en lo que concierne al valor de la prestación. Por último, resulta inadmisible sustentar la dualidad aestimatio rei e $i d$ quod interest $t^{68}$, pues, si bien puede sustentarse en determinados preceptos de nuestro Código Civil, estos no evidenciaría una intención del legislador de establecer una bifurcación del régimen indemnizatorio, sino que sería un vestigio histórico del tratamiento que recibía esta materia en el Derecho Romano, como consecuencia de su sistema de acciones ${ }^{69}$.

De allí que estimemos que resulta relevante abordar la independencia de la acción indemnizatoria, no solo porque existirán casos en que la indemnización de daños será la única opción del acreedor (opción aparente), sino porque puede presentarse supuestos en que debe reconocerse al acreedor un derecho de opción en favor de ella (opción real), tales como la privación de los beneficios que el acreedor esperaba obtener del contrato 160 incumplido, la entrega de una cosa distinta a la convenida que causa daños, el vencimiento del término o plazo esencial, la pérdida de la confianza del acreedor en el futuro cumplimiento del deudor, el incumplimiento de las garantías contractuales y la infracción de los deberes secundarios de conducta ${ }^{70}$.

${ }^{67}$ Alguna doctrina nacional ha sostenido la procedencia de esta distinción tratándose de las obligaciones condicionales, alternativas, facultativas, solidarias e indivisibles, a partir de lo preceptuado en los incisos primero de los artículos 1486 y 1504, en los artículos 1506,1521 y $1526 \mathrm{~N}^{\circ} 3$ y en el inciso segundo del artículo 1533, respectivamente, cfr. Baraona (1997), p. 159; Bustamante (2005), p. 109 y Peñallillo (2009), pp. 335-336. Sin embargo, el tenor del artículo 1678 a propósito de la pérdida de la cosa que se debe da a entender que el precio sería una partida indemnizable y que habrían otras distintas de éste, diluyéndose el argumento según el cual nuestro Código distinguiría el precio de la cosa y la indemnización. Así precisa que si la cosa debida se destruye por un hecho voluntario del deudor, que inculpablemente ignoraba la obligación, deberá "solamente el precio sin otra indemnización de perjuicios”. En igual sentido, AlCAlde (2012), p. 70.

${ }^{68}$ Cfr. López (2014a), pp. 130-138. Postulando la unidad del remedio resarcitorio Morales (2006), pp. 48-50; Pizarro (2007a), pp. 210-212; Díez-Picazo (2008), pp. 781-782; SÁnchez (2010), pp. 1728-1756; Vidal (2011), pp. 765-768 y Alcalde (2012), pp. 57 y 70.

${ }^{69}$ Cfr. Morales (2006), p. 48.

${ }^{70}$ Un análisis detallado de estos supuestos en López (2014a), pp. 157-185. En lo que concierne al vencimiento del término esencial López (2013), pp. 80-87 y al aliud pro alio, LÓPEZ (2014b), pp. 605-624. 
El problema que se ha suscitado es que en algunas ocasiones no se ha invocado la autonomía de la indemnización de daños correctamente y tampoco se han mencionado todos los argumentos que permiten sustentarla en forma irrefutable. De allí que volvamos sobre este tópico, ya no para sustentar su procedencia ${ }^{71}$, sino para constatar en qué casos los tribunales la han acogido y sobre qué premisas la han erigido.

Cabe precisar que nos referiremos solo a las sentencias que se han pronunciado sobre su admisibilidad tratándose de la inejecución de las obligaciones de hacer y de las obligaciones de dar, pues nuestra revisión jurisprudencial arroja que la indemnización exclusiva no se ha desestimado por inejecución de las obligaciones de no hacer ${ }^{72}$.

\section{Casos resueltos por la jurisprudencia reciente en que se admite la procedencia autónoma de la indemnización de daños por incumplimiento contractual}

Una revisión de la jurisprudencia nacional permite constatar que desde el año 2007 a la fecha nuestra Corte Suprema ha admitido progresivamente que el acreedor pueda solicitar la indemnización exclusiva o directa. Se trata, en su mayoría, de supuestos de incumplimiento de una obligación de hacer, lo que constituye un significativo avance, dado que, como lo evidencia el análisis efectuado en la primera parte de este artículo, durante décadas se prescindió del tenor literal del artículo 1553 del Código Civil. Pero a diferencia de lo que pudiera pensarse, la argumentación no solo se sustentó en dicho precepto sino que, en ocasiones, el tribunal justificó su admisibilidad en términos generales, cualquiera fuera la naturaleza de la prestación incumplida, recurriendo a diversas premisas formuladas a partir dela sentencia pronunciada en el caso Opazo Lamana con Inmunomédica Ltda.

Resulta curioso todo este esfuerzo argumentativo, pues como se verá, en algunos casos la Corte Suprema acogió la procedencia de la indemnización exclusiva, pero, en definitiva, la desestimó por no reunirse sus condiciones de procedencia. De allí que estimemos que el verdadero propósito que persiguió dicho tribunal fue preparar la línea argumental para sostener la autonomía de la indemnización en el evento que se presentara

${ }^{71}$ Véase López (2010), pp. 85-103.

${ }^{72}$ Esta opción en favor de la indemnización ha sido reconocida en aquellos casos que un banco ha efectuado cargos en la cuenta corriente de un cliente provenientes de cheques falsificados y en supuestos en que ha girado de la cuenta corriente de un cliente una cantidad de dinero para enviarla a una cuenta ajena como consecuencia de una orden inválida y en supuestos en que ha extraído una suma de dinero de una cuenta corriente sin autorización, véanse las sentencias de la Corte Suprema en Instituto de Normalización Previsional con Banco Santander (2006) y en Coexpan Chile S.A. con Banco Security (2009) y en Coexpan Chile S.A. con Banco Security (2014), respectivamente. 
un supuesto en que, a falta de una norma expresa que facultara al acreedor a optar por la sola indemnización, su procedencia fuera controvertida.

A continuación, efectuaremos un examen cronológico de los casos que hemos pesquisado, consignando los hechos que los configuran con el propósito de determinar si efectivamente se trata de un supuesto de autonomía de la indemnización de daños por inejecución para abordar con posterioridad la pertinencia de los argumentos esgrimidos en cada uno de ellos para acogerla.

\section{i) Transportes Aeropuerto Express Ltda. y LADECO S.A.} (16 de agosto de 2007) ${ }^{73}$ : incumplimiento de la obligación de efectuar reservas del servicio de transporte aéreo

Este es el primer caso en que la Corte Suprema, después de varias décadas, admite la independencia de la indemnización de daños por inejecución de obligaciones de hacer, a partir de lo dispuesto en el numeral tres del artículo 1553, retomando la línea jurisprudencial asentada por las sentencias pronunciadas en los casos Barrios con Rozé, Barthet con Paine y Virgilio y otros con Schiavetti y Hermanos, referidos precedentemente.

Los hechos fueron los siguientes. Transportes Aeropuerto Express Ltda. interpuso demanda de indemnización de daños en contra de LADECO S.A. 162 por la inobservancia de la obligación que imponía el contrato celebrado entre ellas, consistente en efectuar las reservas de sus pasajeros para el servicio de transporte prestado por la demandante que solo cumplió en un principio.

El juzgado de primera instancia rechazó la demanda y condenó al demandante a indemnizar los daños derivados del incumplimiento, invocando al efecto el artículo 1489 y el carácter concurrente y complementario de la indemnización. Ante esta resolución interpuso recurso de casación en la forma y apelación ante la Corte de Apelaciones de Santiago, rechazando dicho tribunal ambos recursos.

En contra de esta última decisión el demandante interpuso ante la Corte Suprema recurso de casación en la forma y en el fondo por infracción de los artículos 13 y 1489 del Código Civil, señalando que en virtud del principio de especialidad, el tribunal debió aplicar el artículo 1553 y no el referido artículo 1489, vulnerando aquel precepto, pues este otorga al acreedor el derecho de solicitar la indemnización compensatoria, sin que sea necesario pedir en forma previa o paralela el cumplimiento o la resolución del contrato. Precisa que dicho artículo es el estatuto específico de las obligaciones de hacer y constituye una excepción a la regla del artículo 1489.

${ }^{73}$ Los hechos han sido extraídos de la sentencia Transportes Aeropuerto Express Limitada con LADECO S.A. (2007). 
La Corte Suprema, en sentencia de 16 de agosto de 2007, acoge la pretensión indemnizatoria, fundamentando su decisión únicamente en la opción que el artículo 1553 del Código Civil otorga al acreedor. Así, en su considerando noveno -que será reproducido en sentencias posteriores ${ }^{74}$ expresa lo siguiente:

"En efecto, la frase de que se sirve la norma- cualquiera de estas tres cosas, a elección suya- da claramente a entender que la indemnización de perjuicios es concebible como solicitud autónoma, sin necesidad de ir aparejada a la petición de cumplimiento o de resolución del contrato de que esa obligación de hacer incumplida emanó"75.

Con todo, el tribunal desestima la indemnización de daños, indicando en su considerando undécimo que no se acreditó que LADECO S.A. hubiera dado cumplimiento a las obligaciones que le imponía el contrato, en especial aquella referida al pago de las comisiones pactadas, de modo tal que de conformidad al artículo 1552 del Código Civil, la mora de la demandada fue purgada por la mora de la demandante y, por consiguiente, falta este presupuesto para acoger la pretensión indemnizatoria.

ii) Opazo Lamana con Inmunomédica Laboratorio Ltda.

(7 de diciembre de 2010 ${ }^{76}$ : incumplimiento de la obligación de entregar un examen preparatorio a una intervención quirúrgica La segunda sentencia en que la Corte Suprema se pronunció respecto de la procedencia de la indemnización exclusiva permite advertir un trascendental progreso en el razonamiento de dicho tribunal, pues no solo supera aquella doctrina que postula que la indemnización no es más que un cumplimiento por equivalente sino que la justifica en términos generales y constituye la primera ocasión en que utiliza la expresión autonomía de la acción indemnizatoria.

Eduardo Opazo Lamana dedujo ante el Segundo Juzgado Civil de Talcahuano demanda de resolución del contrato celebrado con Inmunomédica Laboratorio Ltda., con indemnización de daños, por inejecución de la obligación de entregarle un correcto examen de sangre preparato-

${ }^{74}$ En tal sentido véanse los considerandos quintos de las sentencias Agroindustria San Vicente S.A. con Exportadora Aconcagua Ltda. (2009) y Sociedad Ingeniería y Construcción del Sur S.A. con Fisco de Chile (2012), decimoséptimo de Opazo Lamana con Inmunomédica Ltda. (2010) y décimo séptimo y décimo octavo de Steffen Cáceres con Fundación Mi Casa (2013).

${ }^{75}$ Véase sentencia Transportes Aeropuerto Express Ltda. con LADECO S.A. (2007).

${ }^{76}$ Los hechos han sido extraídos de la sentencia Opazo Lamana con Inmunomédica Ltda. (2010). 
rio a una intervención quirúrgica de su hijo Eduardo Opazo Ziebrecht derivada de un contrato de prestación de servicios médicos. En subsidio solicitó indemnización de perjuicios por responsabilidad extracontractual.

De acuerdo con lo que relata en la demanda, su hijo menor de edad debió realizarse diversos exámenes preparatorios por diagnóstico de varicoceles, uno de los cuales arrojó alteración en la coagulación sanguínea, antecedente que hizo suponer al especialista que el menor padecía una enfermedad hepática o hematológica, ordenándole la realización de nuevos exámenes en un centro de atención distinto. Efectuados tales exámenes se descartó la alteración en la coagulación detectada, sometiéndose el menor a una intervención quirúrgica siete días después. Sin embargo, precisa que la realización de los referidos exámenes le ocasionó perjuicios morales y materiales, afectando la estabilidad familiar y obligándolos a realizar desembolsos económicos adicionales, a lo que se agrega la derivación a otro especialista y el retardo de una cirugía que requería urgencia.

Por su parte, el demandado indicó que es improcedente la resolución de un contrato que contiene una obligación de hacer que se ha cumplido, cuyo carácter es único e instantáneo, de manera que debe desecharse la indemnización de perjuicios que se reclama, toda vez que si no procede la resolución del contrato no puede existir indemnización. En lo que 164 concierne a la demanda subsidiaria de responsabilidad extracontractual también alega su improcedencia, aduciendo que sería contractual, pero como no concurren sus requisitos de procedencia, no se configuraría.

El tribunal de primera instancia sentenció que la demandada efectivamente incumplió su obligación de entregar un examen ajustado a los hechos y condenó a Inmunomédica Laboratorios Ltda. a indemnizar los daños morales resultantes de tal incumplimiento. En contra de dicha sentencia el demandante y el demandado dedujeron recursos de apelación y este último interpuso, además, un recurso de casación en la forma. La Corte de Apelaciones de Concepción rechazó el recurso de nulidad formal y revocó la sentencia de primera instancia, desestimando la indemnización, argumentando que es accesoria y dependiente de la resolución. Con todo, el tribunal precisó que no existió inejecución contractual, porque el examen se realizó, de modo tal que el demandado no estaba facultado para solicitar la resolución del contrato.

Ante esta última decisión el demandante dedujo recurso de casación en la forma y en el fondo ante la Corte Suprema por infracción de los artículos 19 y 1489 del Código Civil, señalando que este último precepto no excluye los contratos de prestación única e instantánea, de manera que siendo claro su tenor literal este no puede desentenderse de conformidad a lo prescrito en el inciso primero del referido artículo 19.

La Corte Suprema, en sentencia 7 de diciembre de 2010, si bien reconoce la autonomía de la acción indemnizatoria en forma expresa, 
no la acoge en definitiva, dado que el demandante no logró acreditar el cumplimiento imperfecto de la obligación que reclama. De allí que la relevancia de esta sentencia no se encuentre en su parte resolutiva, sino que en su parte considerativa, pues, a partir del razonamiento allí contenido, nuestro máximo tribunal comenzará a acoger la tesis de independencia de la indemnización de daños, invocando argumentos esgrimidos por la doctrina nacional reciente, tales como el derecho de opción del acreedor, la reparación integral del daño, el carácter principal de la indemnización y la interpretación lógica del artículo $1489^{77}$, que serán reproducidos en sentencias posteriores.

Así, en lo que concierne a la libre opción del acreedor y la reparación integral del acreedor, consigna lo siguiente:

"Que sobre la materia no puede soslayarse que, conforme a los principios que integran el Código Civil, no se observan particulares motivaciones que podrían inducir a privar a los afectados de dirigir las acciones en la forma y del modo como mejor se ajusten a sus intereses, desde el momento que el derecho civil otorga a las personas el principio de libre disposición de sus bienes y la autonomía de la voluntad, todo lo cual lleva a reconocer las mayores prerrogativas al momento de someter las pretensiones al órgano jurisdiccional. Es por lo anterior que esta Corte Suprema ha reconocido la independencia y autonomía de las acciones indemnizatorias, sean éstas moratorias o perentorias, las que cualquiera sea la naturaleza del objeto de la prestación, pueden impetrarse en forma exclusiva, desde el momento que el legislador ha establecido su procedencia y la forma más usual de interposición, pero no ha prohibido la que en mejor forma repare integralmente el daño derivado del incumplimiento"78.

Por otra parte, a propósito del carácter independiente de la acción indemnizatoria señala:

"Ante la entidad independiente que la ley prevé en general, no existen razones para vincularla de manera determinante con cada una de aquellas acciones de resolución y cumplimiento, como

${ }^{77}$ En tal sentido, PiZArro (2007a), pp. 215-217 y Él MiSMo (2007 b), pp. 151-153; BARRos (2008), p. 409; LÓPEz (2010), pp. 88-97 y 99-113; VIDAL (2011), pp. 771-778 y ELORRIAGA (2012), pp. 1374 y 1376.

${ }^{78}$ Véanse los considerandos décimo cuarto de la sentencia Opazo Lamana con Laboratorio Inmunomédica Ltda. (2010), séptimo de la Asociación de Productores de Huevos de Chile con Banco de Chile (2011), duodécimo de la Toro Fuentealba con Concha Sandoval(2012) y cuarto de la Reyes Valdivia con Escuela de Tripulantes y Portuaria (2012). 
tampoco para entenderla accesoria a las mismas, en especial cuando se reclama la reparación de daños morales. Una razón fundamental surge para ello: tanto la teoría clásica, al considerar que la indemnización es la misma obligación cuyo cumplimiento se logra por medio de la justicia en naturaleza o por equivalencia, como por la teoría moderna que indica que la indemnización es una nueva obligación, lo que permite arribar a la conclusión que se trata de una obligación principal, nunca accesoria" ${ }^{79}$.

Finalmente, refiriéndose a la interpretación lógica del referido artículo 1489, indica lo siguiente:

"En el caso sub lite, se invoca exclusivamente como sustento de la acción el artículo 1489 del Código Civil, sin embargo esta norma frente al estatuto de las obligaciones de hacer, constituye una norma general en materia de incumplimiento de contratos bilaterales, cuya lectura literal y aislada no basta para la decisión de la controversia, de manera que aparece necesario con un fin integrador, y en atención específica al tipo de prestación de que se trata, recurrir a lo dispuesto en el artículo 1553 del Código Civil que solo fue citado por el fallo en análisis" $\$ 0$.

iii) Faúndez Mora con Compañía de Telecomunicaciones de Chile S.A. (20 de junio de 2011) $)^{81}$ : incumplimiento de las obligaciones derivadas de un contrato de suministro telefónico

En este caso Liliam Faúndez Mora demandó a la Compañía de Telecomunicaciones de Chile S.A. (Telefónica Chile) por indemnización del daño emergente, lucro cesante y daño moral causados por el cobro excesivo de tarifa telefónica y el corte de suministro telefónico de una línea que se encontraba en un negocio de su propiedad entre los años 2006 y 2007.

Tal pretensión indemnizatoria fue desestimada por el Juzgado Civil de Tomé, aduciendo su carácter dependiente respecto de la resolución o el cumplimiento a partir de la expresión "con indemnización de perjuicios"

${ }^{79}$ Véanse los considerandos décimo cuarto de la sentencia Opazo Lamana con Laboratorio Inmunomédica Ltda. (2010), duodécimo de la Toro Fuentealba con Concha Sandoval (2012) y séptimo de la Asociación de Productores de Huevos de Chile con Banco de Chile (2011).

${ }^{80}$ Véanse los considerandos décimo cuarto de la sentencia Opazo Lamana con Laboratorio Inmunomédica Ltda. (2010) y séptimo de la Asociación de Productores de Huevos de Chile con Banco de Chile(2011).

${ }^{81}$ Los hechos que a continuación se refieren han sido extraídos de la sentencia de la Corte de Apelaciones Faúndez Mora con Compañía de Telecomunicaciones de Chile S.A. (2011). 
contenida en el inciso segundo del artículo 1489 de nuestro Código Civil. Ciertamente el tribunal no repara en que la norma aplicable en el caso sublite es el artículo 1553 y que debe integrarse con el referido precepto legal, lo que explica en parte su decisión.

Frente a dicha sentencia, el demandante dedujo un recurso de apelación ante la Corte de Apelaciones de Concepción. Dicho tribunal, si bien en su considerando cuarto admite que en este caso el acreedor puede intentar la pretensión indemnizatoria en forma exclusiva o autónoma -citando al profesor Carlos Pizarro-, no la acoge en definitiva, pues estimó que no se acreditó la certidumbre del daño ni la relación de causalidad entre este y la inejecución contractual. En efecto, dicho considerando expresa lo siguiente:

"Para rechazar la responsabilidad contractual [el juez de instancia] estimó que en el presente caso, la acción indemnizatoria no puede ser independiente de la resolución o cumplimiento en su caso. Esta postura, si bien ha sido la que tradicionalmente ha concitado el favor mayoritario de la doctrina, preciso es puntualizar que también existe otra tesis en la que se admite la independencia de la acción indemnizatoria. En efecto, la jurisprudencia ha sostenido la falta de independencia de la acción indemnizatoria en presencia del incumplimiento de una obligación emanada de un contrato bilateral. Para esta posición, al infringirse la obligación el acreedor diligente queda obligado a demandar, ya sea la ejecución forzada o la resolución, pero en ningún caso podría desentenderse de estas acciones y exigir de manera autónoma la indemnización de perjuicios contractuales".

En este punto, Carlos Pizarro Wilson ("La responsabilidad contractual en el Derecho chileno") señala:

“que esta posición hace dependiente la indemnización de perjuicios al ejercicio de la acción resolutoria o aquella de cumplimiento forzado. Sin embargo, no parece razonable que la acción indemnizatoria exija necesariamente ir acompañada de la correspondiente acción de resolución o cumplimiento forzado. Si el acreedor manifiesta su voluntad de obtener la indemnización de perjuicios se desprende que de manera tácita está demandando el término de la relación contractual. La interpretación exegética del artículo 1489 responde a una lectura literal del precepto que obstaculiza la reparación integral del acreedor" ${ }^{\$ 2}$.

${ }^{82}$ Véase considerando cuarto de la sentencia Faúndez Mora con Compañía de Telecomunicaciones de Chile S.A. (2011). 
Lamentablemente el recurso de casación en el fondo interpuesto por el demandante fue desestimado por la Corte Suprema por manifiesta falta de fundamento, toda vez que no se consignaron las normas sustantivas de acuerdo con las cuales debía resolverse el asunto, de modo que no fue posible conocer si dicho tribunal admitía la indemnización exclusiva y, en tal evento, cuáles serían sus argumentos. Lo más probable es que hubiera seguido el razonamiento contenido en la sentencia de segunda instancia, que, si bien resulta pertinente, es innecesario si la obligación incumplida, como ocurre en este caso, es de hacer, toda vez que es suficiente invocar el numeral tres del artículo 1553 del Código Civil.

iv)Asociación de Productores de Huevos de Chile con Banco de Chile (31 de octubre de 2011) ${ }^{83}$ : incumplimiento de la obligación

de verificar el cumplimiento de requisitos formales para el pago cheques emitidos

En esta oportunidad la Corte Suprema una vez más recurre al principio de reparación integral, a la libre opción del acreedor, al carácter principal de la acción indemnizatoria y a la interpretación lógica del artículo 1489 del Código Civil para justificar la indemnización autónoma, reproduciendo literalmente el razonamiento contenido en la sentencia Opazo Lamana 168 con Inmunomédica Ltda ${ }^{84}$.

En consecuencia, no se conforma con el tenor literal del numeral tres del artículo 1553, sino que reitera una contundente argumentación que sirve para justificar la autonomía de la indemnización cualquiera sea la obligación incumplida, aludiendo por primera vez a la regla iura novit curia para instar a los jueces a cumplir su obligación de suplir la errónea interpretación del Derecho.

Los hechos fueron los siguientes: Asociación de Productores de Huevos de Chile demandó la resolución por inejecución de dos contratos de cuentas corrientes bancarias celebrados con el Banco de Chile, solicitando, además, la indemnización de los daños por incumplimiento. En forma subsidiaria demandó tal indemnización a título de responsabilidad civil extracontractual.

El demandante indicó que tomó conocimiento a través de un proveedor de la existencia de facturas impagas y cheques protestados de la Asociación, situación que era desconocida por los directivos. Este hecho determinó que se ordenara una investigación interna que detectó que

${ }^{83}$ Los hechos que a continuación se refieren han sido extraídos de la sentencia de la Corte Suprema Asociación de Productores de Huevos de Chile con Banco de Chile (2011).

${ }^{84}$ Véase considerandos quinto, sexto y séptimo de la sentencia de la Corte Suprema Asociación de Productores de Huevos de Chile con Banco de Chile (2011). 
la secretaria de dicha Asociación efectuó traspasos electrónicos desde una cuenta corriente principal a otra de menor uso, emitiendo cheques en contra de esta última, digitalizando la firma de los socios de la Asociación e imprimiéndolas en cheques emitidos a nombre suyo y cobrándolos personalmente por caja del Banco de Chile, sin que dicho banco formulara reparo alguno. Precisa, además, que en virtud del contrato celebrado con el banco, este se obligó a verificar el cumplimiento de los requisitos formales para proceder al pago de los cheques emitidos por el cuentacorrentista, incumpliendo el demandado esta obligación al pagar cheques cuyas firmas estaban impresas y falsificadas, sin estar convenida ni autorizada esta forma de emisión.

Por su parte, el Banco de Chile indica que la actora incurre en un error conceptual, suficiente para rechazar la demanda de responsabilidad civil contractual, toda vez que el artículo 1489 del Código supone que el contrato esté vigente para solicitar la resolución, en circunstancias de que el contrato de cuenta corriente fue cerrado por la demandante en el mes de abril del año 2006. Agrega que la demandante había aceptado el pago de ciento setenta cheques con firma impresa digitalizada desde diciembre del año 2003 a marzo del año 2005, de modo que solicitar la indemnización de daños constituye una conducta contraria a la teoría de los actos propios, puesto que la referida Asociación entregó por años el manejo de sus cuentas corrientes a una secretaria, sin la debida fiscalización y control, de modo que no puede pretender hacer responsable a terceros de los resultados de una deficiente fiscalización. Por último, admite que existe daño, pero que solo equivale a la presunta diferencia que existe entre la confrontación de las cartolas y los fondos que según la contabilidad deberían existir.

La sentencia pronunciada por el tribunal de primera instancia desestimó la demanda, decisión que fue confirmada por la Corte de Apelaciones de Santiago. La demandante interpuso recurso de casación en el fondo ante la Corte Suprema por infracción de diversas normas, entre las que destaca el artículo 1489 del Código Civil, suscitándose una vez más la discusión en torno a la procedencia autónoma de la indemnización de daños a partir de lo dispuesto en el inciso segundo de dicho artículo.

Nuestro máximo tribunal indicó expresamente que la circunstancia que no resulte procedente la resolución del contrato por encontrase extinto no impide que el tribunal que conoció el fondo del asunto resuelva la controversia, invocando al efecto el principio del iura novit curia. Es en virtud de este argumento que se pronuncia sobre la admisibilidad de la indemnización exclusiva, reconociendo su procedencia y reiterando los argumentos invocados en Opazo Lamana con Inmunomédica Ltda., pero desestimándola en definitiva, porque no se acreditó la inejecución 
contractual denunciada y se constató que la demanda evidenciaba una contravención de los actos propios de la demandante.

v).Toro Fuentealba con Concha Sandoval (13 de junio de 2012 $)^{85}$ : incumplimiento de la obligación de adoptar las medidas de información y prevención para la seguridad e integridad de los trabajadores

En esta oportunidad Claudia Toro Fuentealba interpuso una demanda en contra de Ángel Concha Sandoval y solicitó se le condenara a indemnizar los daños materiales y morales derivados de un accidente que sufrió mientras realizaba su práctica profesional en las instalaciones de la empresa del demandado. Subsidiariamente demandó la responsabilidad extracontractual derivada de dicho accidente.

La demandante indica que en su calidad de alumna de tercer año medio suscribió un contrato denominado "Convenio de Práctica Educacional Regido por el Ministerio de Educación” junto al demandado y al liceo al que ella pertenecía, en virtud del cual aceptó desarrollar su práctica educacional en la empresa Avícola Evita, de propiedad del demandado. Las funciones que se le encomendaron eran recoger huevos de una cinta transportadora y ubicarlos en sus respectivas bandejas para su posterior comercialización.

Agrega que en cumplimiento de dicho contrato sufrió un accidente en las instalaciones de la empresa, que le ocasionó la amputación del dedo anular de la mano derecha y que el demandado no procedió a desarrollar todas las medidas básicas y necesarias de información y prevención para la seguridad e integridad de su persona en el desempeño de sus funciones. Destaca, además, que de haber mediado un actuar diligente en la implementación de tales medidas, el accidente no se hubiera producido, o en cualquier caso, sus efectos hubiesen sido menos dañinos para su persona.

El tribunal de primera instancia desestimó la demanda, indicando que el demandante no precisó en forma clara los hechos, los fundamentos de derecho que le sirven de sustento ni el tipo de responsabilidad que se reclama, omisión que hace improcedente acoger la acción intentada. No obstante, apunta que resulta indudable que se trata de un problema de incumplimiento contractual, de manera que el eventual daño que la actora reclama solo podría haberlo hecho efectivo a través de las reglas de la responsabilidad contractual, conforme lo dispuesto en el artículo 1489 del Código Civil, cuestión que no hizo, ya que solo pidió la indemnización sin haber solicitado previamente la resolución del contrato o su

${ }^{85}$ Los hechos han sido extraídos de la sentencia de la Corte Suprema Toro Fuentealba con Concha Sandoval (2012). 
cumplimiento, razón por la cual rechaza la demanda. Asimismo, precisa que si pretendía demandar en forma subsidiaria la responsabilidad extracontractual, debería haber indicado la fuente de aquella y el hecho ilícito en que habría incurrido el demandado.

En contra de esta decisión el demandante interpone recurso de apelación ante la Corte de Apelaciones de Chillán, confirmando dicho tribunal la sentencia impugnada. Ante dicha resolución el demandante deduce recurso de casación en la forma y recurso de casación en el fondo ante la Corte Suprema, acogiéndose solo el primero de ellos por haber incurrido el fallo recurrido en ultra petita.

En la sentencia de reemplazo de 13 de junio de 2012 el referido tribunal se encarga de indicar que la responsabilidad en que ha ocurrido el demandado es de naturaleza contractual y, al igual que en el caso anterior, aborda el tópico de la autonomía de la indemnización a propósito de la inejecución de cualquier obligación, insistiendo en la misma argumentación que hemos venido revisando a partir del caso Opazo Lamana con Inmunomédica Ltda. Así, en el considerando duodécimo una vez más alude a la libre opción del acreedor, a la reparación integral y al carácter principal de la indemnización.

Con todo, la particularidad de esta sentencia radica en que ella es la primera, de las que venimos revisando, que efectivamente acoge la indemnización exclusiva y condena al demandado al pago del daño moral, precisando incluso que no existe incompatibilidad entre esta y aquellas que la víctima pretenda perseguir por los mismos hechos por coberturas del seguro social, dado que éstas últimas emanan de la ley ${ }^{86}$ y no del hecho generador del daño.

vi). Reyes Valdivia con Escuela de Tripulantes y Portuaria (10 de julio de 2012) ${ }^{87}$ : cumplimiento tardío de la obligación de entregar un título profesional derivado de un contrato de prestación de servicios educacionales

Transcurrido casi un mes de la sentencia antes referida, la Corte Suprema nuevamente debe pronunciarse sobre la admisibilidad de una demanda indemnizatoria por incumplimiento de una obligación de hacer inter-

${ }^{86}$ Así se desprende del artículo $4^{\circ}$ del DS Nº 313 de 1973 del Ministerio de Educación que incluye a escolares en seguros de accidente de acuerdo con la ley $\mathrm{N}^{\circ} 16.744$, pues contempla la administración del seguro por el Servicio de Seguro Social y el Servicio Nacional de Salud, encomendándole al primero el otorgamiento de las prestaciones pecuniarias y al segundo las prestaciones de salud que son financiados en la forma general que prescribe la referida ley $\mathrm{N}^{\mathrm{O}} 16.744$.

${ }^{87}$ Los hechos han sido extraídos de la sentencia de la Corte Suprema Reyes Valdivia con Escuela de Tripulantes y Portuaria (2012). 
puesta por Rodrigo Reyes Valdivia en contra de la Escuela de Tripulantes y Portuaria de Valparaíso. En esta ocasión el demandante alega daños moratorios y lucro cesante por el cumplimiento tardío de la obligación de la demandada de entregarle el título profesional derivado del contrato de prestación de servicios educaciones que habían celebrado, pues ello ocurrió después de seis años de haber egresado de la carrera de técnico en Administración y Comercio, impidiéndole desempeñarse en dicha área.

El juzgado de primera instancia acogió la indemnización. Ante esta decisión el demandante interpone un recurso de apelación ante la Corte de Apelaciones de Valparaíso, tribunal que revocó la sentencia apelada, pues estimó que el daño reclamado no logró acreditarse, dado que la declaración testimonial no tuvo la consistencia necesaria.

Dicha resolución determinó que el demandante interpusiera un recurso de casación en el fondo por infracción del artículo 1553 del Código Civil ante la Corte Suprema, debiendo dilucidar dicho tribunal si tratándose de la inejecución de una obligación de hacer solo basta probar el hecho de la mora del deudor para acceder a la indemnización o si tales perjuicios deben acreditarse en juicio. Citando la triple opción que el artículo 1553 otorga al acreedor de una obligación de hacer, indica que, para ejercer cualquiera de las acciones que otorga dicho precepto, es necesario que 172 el deudor haya sido constituido en mora, admitiendo la autonomía de la indemnización de daños por incumplimiento, recalcando que la ha reconocido en forma reiterada -como lo revelan las sentencias que hemos referido precedentemente-, cualquiera sea el objeto de la prestación incumplida ${ }^{88}$.

Si bien admite la procedencia de la indemnización de daños exclusiva, la desestima, indicando que no concurren todos los requisitos necesarios para que ella resulten procedente, cuales son: el incumplimiento de la obligación, la existencia de daño, el nexo causal entre este y aquel, la imputabilidad del deudor y la ausencia de circunstancias que modifican o eliminan la responsabilidad del deudor, habiéndose acreditado tan solo la mora de este último.

Como se advierte, a diferencia del caso anterior, la Corte, por una parte, vuelve sobre la argumentación específica que justifica la autonomía de la indemnización a propósito de la inejecución de las obligaciones de hacer contenida en la sentencia Transportes Aeropuerto Express Ltda. con LADECO S.A. ${ }^{89} \mathrm{y}$, por otra, una vez más, se pronuncia sobre su

${ }^{88}$ En este sentido reproduce el considerando séptimo de la sentencia Asociación de Productores de Huevos de Chile con Banco de Chile (2011) y duodécimo de la sentencia Toro Fuentealba con Concha Sandoval(2012).

${ }^{89}$ Véase considerando noveno de la sentencia Transportes Aeropuerto Express Limitada con LADECO S.A. (2007). 
admisibilidad general, invocando al efecto la libre opción del acreedor y el principio de reparación integral, en circunstancias que, como hemos venido reiterando, la sola referencia al numeral tres del artículo 1553 era suficiente.

vii) Zorín S.A. con Compañía Siderúrgica Huachipato S.A.

(31 de octubre de 2012) ${ }^{90}$ : entrega de una cosa distinta a la pactada

Las sentencias revisadas hasta aquí evidencian que, salvo el caso Toro Fuentealba con Concha Sandoval, la Corte Suprema solo se había pronunciado sobre la procedencia de la autonomía de la indemnización de daños, pero no la había acogido por no concurrir todas sus condiciones de procedencia.

Es más. Durante el período comprendido entre el 7 de diciembre de 2010 y el 10 de julio de 2012 se advierte una especial preocupación de nuestro máximo tribunal por asentar la teoría de la independencia de la acción indemnizatoria sin constreñirla exclusivamente al incumplimiento de las obligaciones de hacer, sino que formulándola para la inejecución de cualquier obligación. Es como si hubiera ido preparando la línea argumental para sostener la autonomía de la indemnización en el evento que se presentara un supuesto en que, a falta de una norma expresa que facultara al acreedor a optar por la sola indemnización, su procedencia fuera controvertida.

Hasta que finalmente ese caso llegó. Se trata de Zorín S.A. con Siderúrgica Huachipato S.A. que no solo ha concitado la atención de la doctrina nacional porque admite la indemnización autónoma por la inobservancia de una obligación de dar ${ }^{91}$, sino porque también contribuye a asentar las bases dogmáticas del aliud pro alio en nuestro Código Civil ${ }^{92}$.

Los hechos fueron los siguientes. En el mes de mayo de 2007 la referida compañía siderúrgica y la empresa Zorín S.A., celebraron un contrato de compraventa en virtud de cual la primera se obligó a entregar a la segunda mil quinientas toneladas de rodillos de laminación dados de baja por desuso de Níquel, no obstante lo cual la primera partida que entregó carecía de dicha composición. El valor de tales rodillos radicaba en la pureza y riqueza de los componentes químicos que permitiría venderlos a la empresa estadounidense Triorient Trade Inc. y no en la posibilidad de seguir utilizándolos como rodillos, dado que por su desgaste no podían

${ }^{90}$ Véase sentencia de la Corte Suprema Zorín S.A. con Compañía Siderúrgica Huachipato S.A. (2012).

${ }^{91}$ Véase López (2014a), p. 224; De la MAZA-Vidal (2014), pp. 30, 31 y 33; LóPez (2014b), p. 621 y VIDAL (2014), pp. 714-741.

${ }^{92}$ Cfr. López (2014b), pp. 613 y 621. 
refaccionarse ni usarse como tales. Por consiguiente, la entrega de una cosa distinta a la pactada ocasionó daños a la compradora, toda vez que vio frustrada la venta de tales rodillos, privándole de la utilidad que tal negocio le habría reportado.

Atendida la imposibilidad de concretar el negocio con la empresa estadounidense y el daño que el incumplimiento ocasionó a la imagen y prestigio de Zorín, esta demandó la indemnización de daños por inejecución contractual en contra de Compañía Siderúrgica Huachipato S.A., por concepto de daño emergente, lucro cesante, daño moral y daño a la imagen. El referido tribunal acogió la demanda indemnizatoria, invocando al efecto la infracción al principio de buena fe contractual ${ }^{93}$, desechando la excepción de contrato no cumplido y la teoría de la accesoriedad de la indemnización por infracción de una obligación de dar alegadas por la demandada.

Ante esta decisión, el demandante interpuso recurso de casación en la forma y recurso de apelación ante la Corte de Apelación de Santiago, alegando la excepción de cosa juzgada y la prescripción extintiva de las acciones edilicias por vicios redhibitorios y de la acción indemnizatoria del artículo 1861 que eran las que, a su juicio, debió haber opuesto el demandado. Sin embargo, tales excepciones fueron desestimadas por 174 dicho tribunal por no concurrir la triple identidad que exige el artículo 177 del $C P C$ y estimarse que el demandante no ejerció las acciones que el demandado señala ${ }^{94}$, confirmando la decisión de primera instancia, salvo en lo que concierne al daño moral que se tuvo por no acreditado.

El contra de esta sentencia el demandado deduce recurso de casación en el fondo y recurso de casación en la forma ante la Corte Suprema, los que son rechazados, interponiendo el demandante, recurso de casación en la forma que es acogido y determina la dictación de una sentencia de reemplazo. En dicha sentencia de 31 de octubre de 2012, el tribunal resuelve que la entrega de una cosa distinta a la pactada constituye un cumplimiento imperfecto del vendedor, dado que, de conformidad a los artículos 1828, 1568 y 1569 no ha cumplido con su obligación de entregar la cosa convenida ${ }^{95}$. Asimismo, estimó que procede la indemnización au-

${ }^{93}$ Véase sentencia del Quinto Juzgado Civil de Santiago Zorín S.A.con Compañía Siderúrgica Huachipato S.A. (2009).

${ }^{94}$ Consúltese el considerando undécimo. Con todo, como destaca alguna doctrina, la Corte no se pronuncia respecto de un eventual concurso de acciones y la solución que debería darse a este, subsistiendo la inquietud acerca de su admisibilidad, cfr. DE LA MaZa-Vidal (2014), pp. 29-30 y De la MaZA (2014).

${ }_{95}$ Véanse considerandos cuarto de la sentencia de la Corte Suprema Zorín S.A. con Compañía Siderúrgica Huachipato S.A. (2012) y octavo de la Corte de Apelaciones de Concepción SilvaEscandón con Dosque Contreras (1993). 
tónoma, sin que ello implique una vulneración de los artículos 1489 y 1873 del Código Civil, dado que estos no exigen para acoger tal pretensión que el acreedor demande conjuntamente la resolución del contrato ${ }^{96}$. Incluso precisa que, como la misma Corte lo ha resuelto en otras oportunidades, siguiendo una moderna tendencia doctrinal, el demandante puede plantear la indemnización, sin asociarla a la resolución, pues, la entrega material de los rodillos está cumplida y parte de ellos fueron cortados, debiendo considerarse tal indemnización como parte de lo que el vendedor debe en "cumplimiento del contrato, pues según el artículo 1591 el pago total de la deuda comprende el de los intereses e indemnizaciones que se deban" ${ }^{97}$. En atención a estas consideraciones el tribunal acoge la pretensión indemnizatoria, pero solo condena al demandado a indemnizar la suma de 114.400.000 \$ por concepto de lucro cesante ${ }^{98}$.

La relevancia de esta sentencia es innegable, pues evidencia un vuelco en el razonamiento que nuestro máximo tribunal sostuvo durante décadas, según el cual el artículo 1489 del Código Civil consagraba el carácter accesorio, complementario y concurrente de la indemnización por incumplimiento de las obligaciones de dar ${ }^{99}$. Adviértase que la tendencia doctrinal a que se refiere la Corte Suprema es aquella asentada en la causa rol 3341-2009, Opazo Lamana con Inmunomédica Ltda., adhiriendo así al planteamiento que la doctrina nacional reciente había venido postulando desde el año $2007^{100}$, esto es, la libre opción del acreedor, la reparación integral, la interpretación lógica del artículo 1489 y el carácter principal de la indemnización.

${ }^{96}$ Véase considerando décimo cuarto de la sentencia Zorín S.A. con Compañía Siderúrgica Huachipato S.A. (2012).

${ }_{97}$ Op. cit., considerandos noveno y décimo.

${ }^{98}$ Desestima la indemnización por daño emergente, pues la demandante solicitó el coste del corte de los rodillos, en circunstancias que este fue realizado por el comprador, a lo que agrega que es improcedente la restitución de la parte del precio que se pagó a Siderúrgica Huachipato, porque no se solicitó la resolución y los rodillos subsisten en poder del demandante. Rechaza la indemnización por daño moral, indicando que debe acreditarse que la inejecución lesionó la imagen de la empresa, véase considerandos décimo sexto y décimo séptimo de la sentencia Zorín S.A. con Compañía Siderúrgica Huachipato S.A. (2012).

${ }^{99}$ En tal sentido se pronunciaron las sentencias de la Corte de Apelaciones de La Serena en Mac Auliffe con Salinas (1900), de la Corte de Apelaciones de Valparaíso Silva con Sociedad Lafrenz y Díaz (1910), la de Resinas y Terpenos Ltda. con Cía. de Acero del Pacífico S.A. (1993), de la Corte de Apelaciones de la Serena Aranda con MajorDrilling Chile S.A.(2008) y de la Corte Suprema Oviedo con Sociedad Agrícola Sacor Ltda. (2008).

${ }^{100}$ En tal sentido véase Pizarro (2007a), p. 216; ÉL Mismo (2007b), p. 153; Barros (2008), p. 409; De La Maza (2007), pp. 164-165; Corral (2010), pp. 232-233; López (2010), pp. 85 a 103; Vidal (2010), pp. 777-778, Alcalde (2012), p. 58; Elorriaga (2012), pp. 1375-1376 y LóPEZ (2014a), pp. 213-236. 
La decisión de la Corte es acertada, no solo en atención a tales argumentos sino porque, siguiendo los postulados del moderno Derecho Contractual, propende a la satisfacción del interés del acreedor. Y es que el acreedor optó por la indemnización exclusiva, pues, si bien resultaban procedentes la resolución y la pretensión de cumplimiento específico, ellas no satisfacían su interés ${ }^{101}$. En efecto, los rodillos ya habían sido laminados, de modo que aun cuando intentara la acción resolutoria, no hubieran podido restituírseles. Por otro lado, exigirle a Siderúrgica Huachipato que entregara los rodillos convenidos, suponía solicitar a Triorient Trade Inc. la restitución de aquellos recibidos y el envío de los pactados, debiendo soportar Zorín la nueva adquisición y el costo de esa operación.

Lo cierto es que, si bien esta sentencia parece zanjar la discusión en torno a la procedencia de la independencia de la acción indemnizatoria tratándose del incumplimiento de las obligaciones de dar, abre el debate respecto de un tópico que la jurisprudencia solo había referido tangencialmente y en un sentido diverso al que sugiere la sentencia del 31 de octubre de 2012, cual es, el efecto derivado de la autonomía de la indemnización.

La controversia emana del considerando décimo, pues como lo apuntamos en líneas anteriores, este indica que la indemnización a que 176 resulta obligado el vendedor es parte de lo que debe en "cumplimiento del contrato, pues según el artículo 1591, el pago total de la deuda comprende el de los intereses e indemnizaciones que se deban". La interrogante que surge entonces es la siguiente: la indemnización acarrea, ċla subsistencia o extinción del contrato? y tal extinción, ces una resolución tácita o una forma de cumplimiento?

La respuesta variará dependiendo del caso. Lo cierto es que en el último tiempo ha sido precisamente el efecto de la indemnización exclusiva el que ha inquietado a alguna doctrina nacional, sugiriéndose como alternativas la extinción de este por resolución tácita ${ }^{102} \mathrm{o}$ la subsistencia

${ }^{101}$ Un supuesto similar se planteó en el caso Tecdia S.A. con Aceites del Sur S.A. (2005), dado que ambas empresas celebraron un contrato en virtud del cual la primera se obligaba a entregarle a la segunda un millón de latas de "aceite de oliva" para exportarlas a Angola. Transcurridos seis meses y sin que el comprador formulara reclamo alguno, Tecdia S.A. recibió un fax de la Aduana de Cádiz en el que se le informaba que los análisis de muestras tomadas al aceite contenido en dichas latas antes de su envío, había arrojado que se trataba de "aceite vegetal comestible", de modo que debía restituir al Servicio Nacional de Productos Agrarios el beneficio por exportación de aceite de oliva y soportar una sanción. Los tribunales de instancia y el Tribunal Supremo Español acogieron la indemnización exclusiva.

${ }^{102}$ Véase Pizarro (2007a), p. 216. Precisando que la obligación pendiente de cumplimiento se puede extinguir por una especie de resolución tácita o por pago o por la indemnización. cfr. De la MaZA-VIdaL (2014), pp. 33-34. Sin embargo, el segundo autor, en 
del contrato ${ }^{103}$. Coincidimos en que los efectos o consecuencias que se derivan de su interposición pueden ser distintos, pero como lo hemos indicado en otro sitio $^{104}$, no compartimos que uno de ellos sea el que se ha propuesto como primera alternativa.

A nuestro juicio para determinar dicho efecto deben considerarse al menos tres factores:

- la entidad del incumplimiento,

- la forma de ejecución del contrato y

- la cuantía de la indemnización que el acreedor demande. Así, en el evento de que la inejecución contractual sea total o absoluto, como no quedan prestaciones pendientes de ejecución, la indemnización reemplazará al cumplimiento, extinguiendo el contrato. En cambio, si la ejecución es parcial o imperfecta y el contrato es de tracto sucesivo, atendido que aún quedan prestaciones pendientes de ejecución, la indemnización podría reemplazar solo aquellas prestaciones incumplidas, dejando subsistente el contrato (si el monto de la indemnización demandada solo cubre las prestaciones incumplidas) o agotarlo (en el evento que además comprenda aquellas pendientes de ejecución futura). Distinta es la situación si el acreedor frente al cumplimiento imperfecto o parcial de un contrato de ejecución instantánea o diferida demanda la indemnización, toda vez que ella concurrirá junto al cumplimiento específico del contrato o la resolución, en el evento que el acreedor inste por esta última.

Con todo, precisamos que tal extinción del contrato no equivale a su resolución, en atención a dos consideraciones:

- En primer lugar, existe relativo consenso en la doctrina nacional en orden a sostener que para que opere la resolución, ésta debe solicitarse en forma expresa y declararse por sentencia judicial ${ }^{105}$.

otro sitio, también admite que el efecto de demandar de forma exclusiva la indemnización puede ser la conservación del contrato, VIDAL (2011), pp. 774, 776 y 778.

${ }^{103}$ Así Corral (2010), pp. 232-233, a propósito de los contratos de larga duración. En tanto, reconociendo este efecto de la autonomía para la generalidad de los supuestos en que ella se solicite, al menos en su planteamiento inicial, VIDAL (2011), pp. 774, 776 y 778). En igual sentido Elorriaga (2012), pp. 1371 y 1374 y LóPez (2010). pp. 87-88 para la inejecución de un contrato de tracto sucesivo.

${ }^{104}$ Cfr. López (2010), pp. 87-88. En esa oportunidad solo nos detuvimos en la forma de ejecución del contrato e indicamos que si este es de tracto sucesivo, la indemnización permitirá al acreedor seguir vinculado a su deudor, una vez que le indemnice los daños; en tanto, si el contrato es de ejecución instantánea o diferida, la indemnización acarreará su extinción. Con todo, las sentencias pronunciadas por la Corte Suprema entre diciembre de 2010 y septiembre de 2013 nos han llevado a considerar la entidad del incumplimiento y la cuantía de la indemnización como factores adicionales, cfr. LóPEz (2014a), pp. 254-264.

${ }^{105}$ Ilustrativo resulta el planteamiento de Fabián Elorriaga, pues postula que si no se ha solicitado la resolución del contrato, nada puede hacer concluir que la obligación 
En efecto, el juez no puede inferir la voluntad tácita del acreedor en tal sentido.

- En segundo lugar, tal planteamiento equivaldría a sostener que puede sustituirse el medio de tutela escogido por el acreedor, en circunstancias que el juez no puede subrogarse en dicha opción ${ }^{106}$. $\mathrm{Y}$ es que, como lo sostuvimos en su oportunidad ${ }^{107}$, el ejercicio de la acción indemnizatoria en forma autónoma implica la renuncia a demandar el cumplimiento o la resolución del contrato. Miradas las cosas desde esta perspectiva sería el acreedor quien decide cuál es la consecuencia derivada de impetrar la indemnización exclusiva, en la medida que logre acreditar el daño que reclama.

viii) Fisco de Chile con Sociedad Ingeniería Construcción del Sur S.A. (20 de noviembre de 2012) ${ }^{108}$ : inejecución de la obra convenida

Prácticamente un mes después de pronunciada la sentencia Zorín con Siderúrgica Huachipato S.A., la Corte Suprema tuvo que resolver una vez más la procedencia de la indemnización exclusiva por incumplimiento de una obligación de hacer. Pero esta vez, a diferencia de los casos que hemos referido, el demandante fue el fisco de Chile y la obligación incumplida fue la no ejecución de la obra pactada.

178 Los hechos fueron los siguientes: El Ministerio de Obras Públicas del Maule adjudicó la ejecución de la obra Construcción Tenencia Romeral a la empresa Ingeniería y Construcción S.A. Sin embargo, dicha empresa no ejecutó la obra en el tiempo estipulado, motivo por el cual el Director Regional de Arquitectura del referido Ministerio procedió a liquidar el contrato celebrado con la empresa, resultando un saldo en perjuicio del fisco. Atendido que ese saldo equivale al valor de las obras no ejecutadas y del nuevo contrato que este tuvo que celebrar para terminar la obra convenida, dedujo acción indemnizatoria en contra de Sociedad Ingeniería y Construcción S.A., por dicho monto a título de daño emergente, invocando al efecto los artículos 1553 y 1556 del Código Civil.

El demandado, por su parte, indicó que tratándose de un contrato bilateral la demandante debió haber invocado el artículo 1489, según el cual la indemnización es accesoria y dependiente de la resolución o el

del acreedor se extingue, ya que no se ha declarado resuelto, cfr. Elorriaga (2012), pp. 1371 y 1374 .

${ }^{106}$ En tal sentido Verdera (1995), p. 110; TAllon (1994), pp. 235-236; Stijns (2001), p. 524 y RÉmY (2009), p. 255. Véase también el considerando tercero del voto disidente de la sentencia OpazoLamana con Inmunomédica Laboratorio Ltda. (2010).

${ }^{107}$ Cfr. López (2010), p. 87.

${ }^{108}$ Los hechos que a continuación se refieren han sido extraídos de la sentencia de la Corte Suprema Sociedad Ingeniería y Construcción del Sur S.A. con Fisco de Chile (2012). 
cumplimiento. Agrega que el inciso primero del artículo 1999 del Código Civil ubicado a propósito del contrato de confección de obra material prescribe que habrá lugar a la reclamación de perjuicios, según las reglas generales de los contratos, que en este caso es el referido artículo 1489.

El tribunal de primera instancia rechazó la indemnización demandada, indicando que, si bien el artículo 1553 no exige que se haya declarado la resolución o el cumplimiento para solicitar la indemnización, los perjuicios que reclama no se acreditaron. Ante esta decisión el fisco de Chile interpuso recurso de apelación ante la Corte de Apelaciones de Talca, tribunal que revocó la sentencia de primera instancia y acogió la pretensión indemnizatoria, aduciendo que el daño reclamado por la demandante está acreditado, toda vez que la demandada no objetó los documentos que determinaron los perjuicios sufridos por el fisco ni tampoco reclamó de la liquidación del contrato en el plazo legal ${ }^{109}$.

En contra de esta sentencia, Sociedad Ingeniería y Construcción S.A. dedujo recurso de casación en el fondo ante la Corte Suprema por infracción del artículo 1553 del Código Civil, precisando que la sentencia recurrida determinó el monto de los perjuicios en atención a la liquidación del contrato que no solo incluyó los gastos que deben considerarse como daño emergente y lucro cesante sino que, además, el mayor costo en que se incurrió al contratar a un tercero para terminar la obra, esto es, la pretensión de cumplimiento contenida en numeral dos del artículo 1553. Así las cosas, precisa que la sentencia debió limitar su pronunciamiento a las sumas contempladas en el numeral tres de ese precepto, dado que el fisco no ejerció la referida pretensión de cumplimiento.

Sin embargo, la Corte Suprema acogió la pretensión indemnizatoria del demandante, confirmando que el mayor costo que le significó la celebración de un nuevo contrato para la conclusión de la obra convenida tiene naturaleza resarcitoria, precisando que la reparación de ese daño se obtiene a través del numeral tres del referido artículo 1553. A continuación, justifica la procedencia autónoma de la indemnización aludiendo al triple derech $0^{110}$ que dicho precepto consagra en favor del acreedor y reiterando la argumentación que esgrimió en la sentencia del caso Transportes Aeropuerto Express Limitada y LADECO S.A. Así expresa lo siguiente:

${ }^{109}$ Véase sentencia de la Corte de Apelaciones de Talca Fisco de Chile con Sociedad Ingeniería y Construcción del Sur S.A. (2012).

${ }^{110}$ Esta expresión ya había sido utilizada por este mismo tribunal en los considerandos octavo de la sentencia Transportes Aeropuerto Express Ltda. con LADECO S.A. (2007), décimo séptimo de la Opazo Lamana con Inmunomédica Laboratorio Ltda. (2010) y cuarto de la Reyes Valdivia con Escuela de Tripulantes y Portuaria(2012). 
"El acreedor puede solicitar la indemnización compensatoria aun cuando fuere posible el cumplimiento forzado por naturaleza, puesto que el precepto en estudio lo deja a su opción. En efecto, la frase de que se sirve la norma 'cualquiera de estas tres cosas', a elección suya da claramente a entender que la indemnización es concebible como solicitud autónoma, sin necesidad de ir aparejada a la petición de cumplimiento o de resolución del contrato cuando se trate de obligaciones de hacer incumplidas" ${ }^{111}$.

Abandona, en consecuencia, la argumentación general respecto de la admisibilidad de la autonomía de la indemnización que había sostenido en sentencias anteriores en que solo debía pronunciarse sobre la inejecución de las obligaciones de hacer y focaliza su atención en un razonamiento más específico. Con todo y atendido que el demandante también reclamó la ejecución imperfecta de algunos tramos de la obra, hubiera sido conveniente que la Corte, para reforzar su decisión, aludiera, al menos en esta parte, al artículo 2002 del Código Civil, puesto que el inciso segundo de dicho precepto permite al que encargó la obra solicitar al artífice la indemnización de daños derivada de dicha ejecución. De esta forma la alegación del demandado según la cual el artículo 1553 sería improcedente 180 porque la regla general contenida en el artículo 1999 es la dependencia de la indemnización, quedaría sin sustento, toda vez que dicha regla debería reinterpretarse a la luz del numeral 3 del artículo 1553 y a partir del referido inciso segundo del artículo 2002.

ix) Ampuero Asencio con Castillo Hernández (28 de enero de 2013) ${ }^{112}$ : incumplimiento del mandatario judicial de la obligación de distribuir en forma convenida el monto percibido de un avenimiento laboral El examen de las sentencias pronunciadas por la Corte Suprema que hemos realizado hasta acá, nos podría inducir a pensar que la discusión entorno a las distintas aristas derivadas de la autonomía de la indemnización estaba superada no solo en nuestra jurisprudencia sino, también, en la doctrina nacional y que ella no admitía mayor cuestionamiento.

Lo cierto es que hasta ahora la discusión era más bien teórica que real, porque salvo los casos Toro Fuentealba con Concha Sandoval, Zorín con Siderúrgica Huachipato S.A.y fisco de Chile con Sociedad Ingeniería Construcción del Sur S.A., no se había concedido la indemnización de

${ }^{111}$ Véase considerando quinto de la sentencia Fisco de Chile con Sociedad Ingeniería y Construcción del Sur S.A. (2012).

${ }^{112}$ Véase sentencia de la Corte Suprema Ampuero Ascencio con Castillo Hernández (2013). 
daños. Por consiguiente, no había surgido el debate doctrinario entorno a la calificación jurídica de la pretensión del demandante por inejecución de las obligaciones de dar ni la necesidad de distinguir entre el id quod interest y la aestimatio rei.

En este caso los hechos fueron los siguientes: José Ampuero suscribió un contrato de honorarios por servicios profesionales de cuota litis con Alfonso Castillo Hernández con el objetivo que este asumiera, en calidad de abogado, su representación judicial y la de otros cinco trabajadores en un juicio laboral en contra de su ex empleador. Las partes del litigio llegaron a un avenimiento que puso término al referido pleito y que consideró el pago por parte de la empresa demandada, correspondiendo al demandante un porcentaje superior al de los restantes actores, en atención al mayor tiempo de prestación de servicios para su ex empleador.

Sin embargo, Alfonso Castillo Hernández dividió el dinero en forma unilateral y sin utilizar ningún criterio lógico, lo que provocó que el demandante recibiera una suma menor a la que le correspondía, pues sus codemandantes, con menor tiempo trabajado, obtuvieron un monto que osciló entre $650.000 \$ y$ 1.600.000 \$ por sobre lo que a él le correspondió. Esta circunstancia determinó que interpusiera una acción indemnizatoria y reclamara el daño emergente y el daño moral derivados del incumplimiento.

El demandado, por su parte, alegó la prescripción extintiva de la acción indemnizatoria y contestó la demanda indicando que a falta de un acuerdo de efectuar una distribución distinta de los fondos obtenidos, procedió a asignarlos en partes iguales.

El tribunal de primera instancia desestimó la indemnización de daños, acogiendo la excepción de prescripción deducida por el demandado. Ante esta decisión el demandante interpuso recurso de apelación ante la Corte de Apelaciones de Puerto Montt, tribunal que revocó la sentencia recurrida, en cuanto no acogió la excepción de prescripción y la confirmó en lo relativo al rechazo de la demanda, indicando que de conformidad al artículo 1489 del Código Civil, para solicitar la indemnización de daños debe demandarse en forma principal el cumplimiento o la resolución del contrato.

En contra de esta última sentencia, el demandante dedujo recurso de casación en el fondo ante la Corte Suprema, tribunal que anuló de oficio la sentencia pronunciada, toda vez que ella omitió las consideraciones de hecho y de derecho que debían servirle de fundamento y dictó la sentencia de reemplazo pertinente. En dicha resolución precisó que el mandatario incumplió su obligación, pues no restituyó al actor lo que le correspondía al tenor de lo pactado, motivo por el cual acoge la indemnización reclamada -que según expresa el tribunal equivale a "la diferencia existente 
entre lo que percibió y aquello que efectivamente le correspondía"-, pero en virtud del estatuto jurídico del mandato.

Si bien la Corte determinó que la pretensión reclamada por el demandante efectivamente tenía un carácter indemnizatorio, alguna doctrina ha sostenido que estaríamos ante el cumplimiento específico de una obligación de dar ${ }^{113} \mathrm{y}$, por consiguiente, ante un caso aparente de autonomía de la indemnización. A partir de este planteamiento la cuestión que surge es la siguiente: ¿cuál es la naturaleza jurídica del valor de la prestación o aestimatio rei?: ¿daño intrínseco o cumplimiento por equivalente?

Sabido es que la respuesta a esta interrogante ha concitado la atención de la doctrina comparada y nacional desde hace algunas décadas y existen interesantes argumentos para sustentar una u otra postura. Sin embargo, a nuestro juicio, tal debate cobra relevancia en aquellos casos en que el tribunal desestime una pretensión de cumplimiento, exigiendo al demandante la concurrencia de las condiciones de procedencia de la indemnización ${ }^{114}$, lo que no ocurre en este caso, de modo que deviene en innecesario.

Con todo, y en el bien entendido que para dicho tribunal la pretensión reclamada es indemnizatoria y que solo estaba otorgando el daño emergente por incumplimiento del mandato, no era necesario discurrir sobre la admisibilidad de la autonomía de la indemnización de daños. 182 No obstante, dicho tribunal aborda este tópico con el propósito de refutar la argumentación contenida en la sentencia de primera instancia que desestimó la pretensión indemnizatoria invocando por la accesoriedad y dependencia de la indemnización a que alude el artículo 1489.

Así, siguiendo la misma línea argumental que hemos venido revisando, justifica la autonomía de la indemnización en la libre opción del acreedor, la reparación integral del daño y el carácter independiente de la indemnización ${ }^{115}$, pero acoge la pretensión indemnizatoria sin recurrir a dicho razonamiento, toda vez que el contrato incumplido, como advierte el tribunal, se encuentra regido por un estatuto jurídico particular que permite perseguir la indemnización de perjuicios en contra del mandatario de conformidad a la normativa contenida en el título xxIX del libro cuarto

${ }^{113}$ En tal sentido De LA MAZA-VIDAL (2014), p. 34 quienes precisan que no pretenden negar la procedencia de la autonomía de la indemnización tratándose de las obligaciones de dar, sino evidenciar que pueden existir casos que induzcan a confusión.

${ }^{114}$ De hecho este es uno de los argumentos esgrimidos por los autores que sustentan la autonomía del equivalente pecuniario, pues aducen que su equiparación a la indemnización de daños resulta perjudicial para el acreedor, puesto que al subsumir el primero en la segunda, este resulta obligado a acreditar la imputabilidad del deudor, en circunstancias que el cumplimiento específico opera al margen de su culpa o dolo, cfr. Castilla (2001), p. 278; Llamas (1999), p. 288 y Baraona (1997), p. 160.

${ }^{115}$ Véase el considerando vigésimo de la sentencia Ampuero con Castillo (2013). 
del Código Civily que surge principalmente de la aplicación de los artículos 2131, 2129, 2154, 2155 y 2157 de dicho cuerpo legal.

De allí que el tribunal señale que en este caso

"no incide la posición doctrinaria que se tenga respecto de la necesidad de impetrar alguna de las acciones que concede el artículo 1489 del mismo Código para demandar perjuicios"116,

lo que únicamente permite evidenciar que la prevención que realiza en el considerando vigésimo, a propósito de la autonomía de la indemnización de daños por inejecución contractual, obedece a su particular preocupación por reiterar la argumentación sobre la que ha erigido su procedencia.

x). Steffen Cáceres con Fundación Mi Casa (10 de septiembre de 2013) ${ }^{117}$ : Incumplimiento de la obligación de restituir el inmueble arrendado y del pago de las rentas La revisión de las sentencias que hemos venido efectuando nos ha permitido constatar que, por lo menos hasta aquí, todas ellas han identificado correctamente aquellos supuestos en que el tribunal debe acoger la pretensión indemnizatoria en forma exclusiva. Un fenómeno distinto se advierte en el fallo pronunciado por la Corte Suprema en el caso Steffen Cáceres con Fundación Mi Casa, pues cabe preguntarse si es un verdadero caso de independencia de la indemnización de daños, independientemente de que se adhiera, como lo hacemos nosotros, a la unidad del remedio resarcitorio y se desestime aquella postura doctrinal que aboga por la distinción entre el id quod interesty la aestimatio $r e i^{118}$.

Y es que, como se advertirá, en este caso el problema consiste en determinar si la pretensión deducida por la demandante solo es indemnizatoria o, por el contrario, se reclama, además, el cumplimiento específico del contrato, supuesto en el cual la indemnización dejaría de ser autónoma y pasaría a ser complementaria.

Los hechos son los siguientes: María Gisella Steffen Cáceres celebró con Fundación Mi Casa un contrato de arrendamiento de un inmueble con el propósito de destinarlo a albergar las dependencias de la residencia de vida familiar Vilma Reyes, entidad subvencionada por el SENAME, incendiándose éste por negligencia de la arrendataria y sus administradores.

La arrendadora demandó la terminación del contrato por falta de pago de la renta convenida y la indemnización de daños, solicitando el

${ }^{116}$ Véase considerando vigésimo primero de la sentencia Ampuero con Castillo (2013).

${ }^{117}$ Los hechos han sido extraídos de la sentencia Steffen Cáceres con Fundación Mi Casa (2013).

${ }^{118}$ Sobre esta discusión doctrinaria véanse los autores indicados en las n 63-65. 
pago de las rentas adeudadas a partir de julio de ese año por concepto de lucro cesante y la restitución del inmueble en el mismo estado en que se recibió, a título de daño emergente.

La arrendataria, por su parte, solicitó el rechazo de la demanda, negando adeudar las rentas de arrendamiento reclamadas con posterioridad al siniestro, aduciendo que el inmueble estaba destruido, de modo que no podía servir para el fin contratado. Precisa además que envió cartas a la demandante exponiendo que con fecha 30 de junio de 2011 entregaba el inmueble y sus llaves, con sus consumos al día. En cuanto a la indemnización señaló que no se acreditó que alguno de los albergados en el inmueble hubiere ocasionado el siniestro, faltando la relación causal entre este y aquellos.

El tribunal de primera instancia rechazó la demanda de terminación del contrato y acogió la indemnización de perjuicios a título de daño emergente y lucro cesante. Frente a esta decisión ambos litigantes interpusieron recurso de apelación ante la Corte de Apelaciones de Valdivia, tribunal que confirmó la decisión apelada, indicando que la acción indemnizatoria es independiente de la acción de terminación del contrato y que el contrato terminó por culpa de la arrendataria.

En contra de esta sentencia la demandada dedujo recurso de casación en el fondo por infracción de los artículos 1489, 1545 y 1557 del Código 184 Civily de las normas reguladoras de la prueba. En lo que concierne a la vulneración del primer precepto -que es el que nos interesa-indica que si la obligación incumplida es la de pagar las rentas, la arrendadora no puede pedir la indemnización, sino cuando el cumplimiento del contrato se ha hecho imposible por pérdida de la cosa debida, cuestión que no ha ocurrido en este caso. Así, precisa que rechazada la acción de terminación del contrato, la indemnizatoria acogida carece de basamento legal.

La Corte Suprema en sentencia de 10 de septiembre de 2013 rechazó el recurso de casación interpuesto por estimar que la acción indemnizatoria es independiente de la acción de terminación del contrato, admitiendo la procedencia de la indemnización autónoma. En tal sentido indica que una nueva interpretación que este tribunal ha venido amparando otorga al contratante incumplidor el derecho de demandar indistintamente el cumplimiento especifico, la resolución o la indemnización de perjuicios para lo cual debe determinarse el sentido y alcance del artículo 1489 del Código Civila la luz de su contexto, pero vinculándolo a otras normas del mismo cuerpo legal, en especial aquellas relacionadas con el cumplimiento de las obligaciones de hacer y no hacer. A continuación se refiere al triple derecho que el artículo 1553 otorga al acreedor, reproduciendo literalmente la argumentación contenida en el considerando noveno de la sentencia Transportes Aeropuerto Express Ltda. con LADECO S.A., séptimo de la sentencia Opazo Lamana con Inmunomédica Laboratorio Ltda. (2010) y cuarto de la sentencia Reyes Valdivia con 
Escuela de Tripulantes y Portuaria (2012). Incluso, la Corte indica que entre el inciso segundo del artículo 1489 y el artículo 1553 existiría una aparente colisión normativa que corresponde resolver de acuerdo con el elemento lógico de interpretación contenido en el artículo 22 del Código Civil ${ }^{119}$.

Sin duda la argumentación de la Corte Suprema en favor de la autonomía de la indemnización es contundente y congruente con la asentada en casos precedentes. Con todo, y como hemos anticipado, en este caso surge la siguiente pregunta: ¿es un auténtico caso de autonomía? Como ha indicado algún autor ${ }^{120}$ no lo es, pero estimamos, a diferencia de lo que este ha sostenido, que no se trata solo de una pretensión de cumplimiento específico. A nuestro juicio la Corte acogió dicha pretensión, pero acompañada de una indemnización complementaria. En efecto, la reclamación que dicho tribunal otorga es la que el demandante denomina daño emergente, pero que en realidad equivale a la restitución del inmueble -esto es, al cumplimiento específico- y el lucro cesante que en este supuesto comprende las rentas que dejó de percibir hasta el término del contrato.

En consecuencia, en este caso creemos que efectivamente existe una autonomía aparente de la indemnización de daños o, si se quiere, un supuesto de indemnización complementaria. Surge, entonces, la necesidad de que el tribunal determine, en cada supuesto de incumplimiento que deba conocer, el contenido indemnizatorio de la pretensión reclamada ${ }^{121}$, pues de lo contrario, a poco andar, la independencia para impetrar la indemnización exclusiva se diluirá, desdibujándose el sistema de acciones o remedios por incumplimiento que en los últimos años ha intentado sistematizar la doctrina nacional y confundiéndose, como ha ocurrido en este caso, la pretensión de cumplimiento con la indemnización de daños.

xi )Stange contra Ripley Puerto Montt (2 de octubre de 2013) ${ }^{122}$ : Incumplimiento de un contrato de transacción

$\mathrm{El}$ examen de la jurisprudencia que hemos venido consignando revela que, más allá de las discusiones en torno al contenido indemnizatorio de

${ }^{119}$ En tal sentido véanse los considerandos décimo séptimo y décimo octavo de la sentenciaSteffen Cáceres con Fundación Mi Casa (2013).

${ }^{120}$ Cfr. Contardo (2014), pp. 267-268. El autor sostiene que las rentas impagas no constituyen lucro cesante, sino el cumplimiento de la obligación principal del arrendatario, cual es el pago de la renta. Como se advierte, coincidimos en que se trata del valor de la prestación, pero discrepamos respecto de su naturaleza jurídica.

${ }^{121}$ Advirtiendo este mismo fenómeno, pero desechando el carácter indemnizatorio de la prestación reclamada en el caso Ampuero Ascencio con Castillo Fernández y Steffen Cáceres con Fundación Mi Casa, respectivamente, De LA MAZA-VIDAL (2014), p. 34 y Contardo (2014), pp. 267-268.

${ }^{122}$ Los hechos que a continuación se refieren han sido extraídos de la sentencia Stange contra Ripley Puerto Montt (2013). 
la pretensión alegada, la Corte Suprema ha acogido la indemnización exclusiva en los casos Zorín con Siderúrgica Huachipato S.A., Fisco de Chile con Sociedad Ingeniería Construcción del Sur S.A., Ampuero Ascencio con Castillo Hernández y Steffen Cáceres con Fundación Mi Casa.

A ellos se agrega un último caso que revisaremos, caratulado Stange contra Ripley Puerto Montt, que ha sido el más publicitado,porque la demandada y finalmente condenada al pago de indemnización, fue una reconocida multitienda internacional que incumplió un contrato de transacción celebrado con el demandante.

En esta ocasión los hechos fueron los siguientes. Eduardo Stange Hoffman dedujo demanda de indemnización por concepto de daños materiales y por daños morales en contra de Ripley Puerto Montt (South Store S.A.) derivados de la inejecución de un contrato de transacción celebrado entre ellos en mayo de 2005. Precisa que en virtud de dicho contrato se transó con la demandada una deuda no reconocida por él, en virtud de la cual debía pagar un poco menos de la mitad de su valor. Ripley Puerto Montt, por su parte, se obligaba a darle un plazo de sesenta días para pagar la deuda y a eliminar su nombre del DICOM, una vez firmado el referido acuerdo y pagada dicha suma. No obstante, el demandado incumplió esta última obligación, publicando el nombre del demandante en el referido 186 Boletín respecto de la referida deuda, a pesar de que por expreso acuerdo de las partes esta se había remitido.

El demandado, por su parte, solicitó el rechazo de la demanda, aduciendo que de conformidad con el artículo 1489 del Código Civil la indemnización por incumplimiento contractual solo puede demandarse juntamente con el cumplimiento específico o la resolución del contrato, a diferencia de lo que ocurre en sede extracontractual en que ella puede solicitarse en forma directa.

El tribunal de primera instancia acoge la pretensión indemnizatoria solo en lo que concierne al daño moral, dejando establecido que se accionó por concepto de responsabilidad civil extracontractual. En contra de esta decisión el demandado interpuso recurso de casación en la forma y apelación, no obstante lo cual la sentencia impugnada fue confirmada por la Corte de Apelaciones de Puerto Montt.

Frente a esta resolución el demando dedujo recurso de casación en la forma ante la Corte Suprema, denunciando que incurrió en ultra petita. Dicho tribunal en sentencia de 2 de octubre de 2013 acoge el recurso de casación interpuesto y dicta sentencia de reemplazo, admitiendo el ejercicio de la indemnización autónoma y condenando al demandado a pagar daño moral derivado del incumplimiento, ya que lesionó la honra del demandante.

El tribunal una vez más aborda la independencia de la acción indemnizatoria, cualquiera sea el objeto de la prestación incumplida, advirtiendo: 
"la indemnización de perjuicios, pura y simple, se encuentra engarzada con lo que se puede resolver respecto de la procedencia o improcedencia de reclamarla directamente, con total independencia de las restantes hipótesis que en materia contractual y, para el caso de incumplimiento, contempla el artículo 1489 del Código Civil”.

De hecho, se detiene a justificar la admisibilidad de la indemnización exclusiva, reproduciendo textualmente los considerandos contenidos en las sentencias que ya hemos analizado y que aluden a la libre opción de del acreedor, la reparación integral del daño y el carácter principal de la indemnización ${ }^{123}$, aun cuando tratándose de la inejecución de una obligación de hacer bastaba con aludir al artículo $1553 \mathrm{~N}^{\circ} 3$ del Código Civil.

xii) Laboratorios de Control Técnico Llay Llay Ltda.

con Celestron Ltda. (26 de noviembre de 2014) ${ }^{124}$ :

Cumplimiento imperfecto de la obligación

de transferir un equipo y participar en su instalación

El último caso que se revisará, adquiere una connotación especial por su reciente data y porque constata que la incertidumbre respecto de la procedencia de la autonomía de la indemnización de daños por incumplimiento de una obligación de dar comienza a diluirse, aun cuando una primera lectura de la sentencia pronunciada por la Corte Suprema pudiera conducir a una conclusión contraria.

Los hechos fueron los siguientes: En el mes de julio de 2007, Laboratorios de Control Técnico Llay Llay Ltda. adquirió de Celestron Ltda. una consola de Control Automatic, Automax 5, modelo 50-Q5112, serie Nº7010015 de origen italiano, para modernizar una antigua máquina manual alemana que realiza ensayos de densidad y otras pruebas de hormigón y cemento para terceros. Sin embargo, dicha consola fue entregada con daños provocados durante el transporte internacional, motivo por el cual se efectuó una nueva importación de las partes dañadas para repararla, lo que determinó que el equipo no pudiera ocuparse durante ocho meses. Posteriormente, como consecuencia de la diferencia existente entre los resultados de los informes emitidos por uno de sus clientes y las contra muestras que ellos realizaron, se efectuó una revisión de los procesos y se solicitó al IDIEM una recalibración del equipo. Pese a ello, la consola presentó una serie de desperfectos, circunstancia que ocasionó el cese

${ }^{123}$ Véase el considerando décimo noveno de la sentencia Stange con Ripley Puerto Montt (2013).

${ }^{124}$ Los hechos de este caso han sido extraídos de la sentencia Laboratorios de Control Técnico Llay Llay Ltda. con Celestron Ltda. (2014). 
de la relación comercial de Laboratorio Técnico con la empresa Lafarge Hormigones S.A., causándole un lucro cesante considerable.

Atendido que Celestron Ltda. se obligó a vender al demandante un equipo de alta tecnología para ser instalado en una máquina más antigua y participar en su instalación, Laboratorio de Control Técnico Llay Llay demandó la indemnización por incumplimiento contractual, solicitando que se le condenara a pagar el daño emergente -representado por el valor de la máquina- y el lucro cesante derivado del cese de la relación comercial con la referida empresa. El demandado, por su parte, indicó que, si bien la demandante compró el equipo en cuestión, esta ocuparía algunas partes de la máquina antigua, sustituyendo algunas mecánicas y analógicas, por otras nuevas, automáticas y electrónicas. Agregó, además, que la demandante optó por encargar el trabajo de instalación y modernización a otra empresa que no supo realizar las adaptaciones con el equipo antiguo, desconfigurándolo, pero que igualmente asumió su calibración y lo dejó apto para emitir certificados válidos bajo normas nacionales.

El tribunal de primera instancia, en sentencia de 25 de noviembre de 2011, admitió la indemnización autónoma solicitada, indicando que, si bien no existe certeza de que las fallas de la máquina se debieron a los defectos de esta o a su mala instalación, ambas circunstancias eran de cargo de Celestron Ltda. Sin embargo, la Corte de Apelaciones de Santiago, conociendo de un recurso de apelación interpuesto por el demandado, desestimó su procedencia, aduciendo el tenor literal del artículo 1489. Así, en la sentencia de 12 de septiembre de 2013, expresa lo siguiente:

"Que de lo anterior, se desprende que ante el incumplimiento de uno de los contratantes, el otro tiene derecho de pedir la resolución o el cumplimiento del contrato, y en su caso, como un derecho secundario, la compensación de los daños que el incumplimiento total o parcial le haya ocasionado".

La jurisprudencia así lo ha reconocido, al señalar:

"La obligación de indemnizar nace como consecuencia del incumplimiento o cumplimiento imperfecto o tardío de aquello a que el deudor se obligó, pero solo se entiende si se ha declarado, a su vez, la resolución del contrato o se ha dispuesto su cumplimiento" ${ }^{125}$.

Ante esta sentencia, el demandante dedujo recurso de casación en el fondo por infracción del artículo 1489, pues, a su entender, dicho precepto

${ }^{125}$ Véase el considerando sexto de la sentencia Laboratorio Control Técnico Llay LLay con Celestron (2013), pp. 145-147. 
permite demandar la indemnización exclusiva. La Corte Suprema, en sentencia de 26 de noviembre del presente año, acoge el recurso, admitiendo la procedencia de la indemnización autónoma por incumplimiento, invocando, una vez más, la interpretación lógica del artículo 1489 del Código Civil, el principio de reparación integral del daño, la libre opción del acreedor y el carácter principal de la indemnización ${ }^{126}$, reproduciendo el razonamiento vertido en las sentencias que hemos venido revisando.

Hasta aquí podría pensarse que nuestro máximo tribunal acogió la indemnización exclusiva por incumplimiento de una obligación de dar. Sin embargo, de forma sorprendente en el considerando séptimo de dicha sentencia, precisa que la obligación incumplida es de hacer, pues: "junto con proveer del equipo debió prestar la asesoría técnica para su instalación y correcta operación", indicando en el considerando siguiente que el tribunal de alzada infringió lo preceptuado en el referido artículo 1489 y que la equivocada aplicación de dicha norma llevó a los sentenciadores del fondo a desestimar la indemnización solicitada.

Como podrá intuirse, la sentencia pronunciada en este caso evidencia un nuevo inconveniente que no se había avizorado tan claramente en Zorín con Siderúrgica Huachipato S.A. ${ }^{127}$ y en Cuadra Calderón con Céspedes Arteagabeitía ${ }^{128}$, cual es, la errónea calificación de la obligación incumplida y la contradictoria determinación del estatuto jurídico aplicable a las obligaciones de dar. En efecto, en ambos casos resulta claro que la prestación no ejecutada era de esta especie, dado que consistió en transferir el dominio de determinadas toneladas de rodillos y en ceder los derechos en una sociedad comercial, respectivamente. Su naturaleza no fue objeto de discusión en el primero de estos casos, dado que la Corte Suprema no calificó la obligación incumplida, aunque resultaba evidente que era de dar. En tanto, en el segundo, dicho tribunal resolvió -a diferencia de lo que habían establecido los de instancia- que la obligación era de dar y no de hacer, pues a través de la referida cesión se estaba transfiriendo el dominio de tales derechos.

Un fenómeno diverso se aprecia en el caso que venimos comentando, pues, si bien el demandante no calificó la obligación infringida en su libelo, quedó establecido que esta consistía en entregarle un equipo con la intención de transferirle el dominio y en prestar asesoría para su correcta instalación y operación. En consecuencia, la obligación incumplida por Celestron Ltda. no era solo de hacer, como lo resolvió la Corte

${ }^{126}$ Cfr. considerandos cuarto, quinto y sexto de la sentencia Laboratorio Control Técnico Llay LLay con Celestron (2014).

${ }^{127}$ Sobre los hechos de este caso véase infra II.1.vii.

${ }^{128}$ Sobre los hechos de este caso véase n. 38 . 
Suprema, sino que, además, de dar, toda vez que esta última no puede ser absorbida por la primera, pues ellas mantienen su existencia separada e independiente. Resulta curioso y contradictorio que el tribunal efectué tal calificación de la obligación, soslayando la existencia de una obligación de dar, pero sostenga que el precepto que se vulnera es el artículo 1489; más aún considerando que en Cuadra Calderón con Céspedes Arteagabeitía, resolvió que la prestación no ejecutada era de dar y que era improcedente la indemnización solicitada, porque se invocó la infracción del artículo 1553 del Código Civil, en circunstancias que el estatuto aplicable para dicha obligación era el artículo 1489 de dicho cuerpo normativo.

Miradas las cosas desde esta perspectiva, pareciera que al igual que en dicho caso -en que, si bien precisó que el estatuto de las obligaciones de dar era el artículo 1489, pero no indicó si admitía la indemnización autónoma- la Corte Suprema evitó pronunciarse de manera abierta sobre la procedencia de la indemnización autónoma por incumplimiento de las obligaciones de dar, aun cuando en los considerandos anteriores reiteró la contundente argumentación contenida en sentencias precedentes, otorgándola en definitiva. De ahí que sostengamos que, en realidad, esta sentencia disipa, aunque de forma encubierta, la incertidumbre respecto a la admisibilidad de la indemnización de daños en este tipo de obligaciones.

190 Con todo, podría pensarse que, si bien este proceder no es el más correcto desde una perspectiva dogmática, en nada perjudica al acreedor, pues igualmente se le otorga la pretensión reclamada. Lo cierto es que genera inseguridad jurídica, dado que no existe claridad respecto de los parámetros para calificar de modo jurídico a una obligación como de dar o de hacer ni la normativa que autorizaría para demandar la indemnización exclusiva en el evento de no ser ejecutada, surgiendo una interrogante que a la fecha estaba prácticamente resuelta: ¿el estatuto aplicable a las obligaciones de hacer es el artículo 1553 o el artículo 1489?

Frente a esta incerteza pareciera más conveniente que el acreedor demandara la indemnización exclusiva sin calificar la obligación incumplida o, bien, precisando el objeto de la prestación e invocando de manera conjunta ambos preceptos legales, alternativa esta última que no parece adecuada, particularmente para las obligaciones de dar. Surge así la necesidad de resolver este inconveniente, lo que, a nuestro juicio, solo ocurrirá en la medida que los tribunales confieran dicha indemnización, admitiendo que la obligación incumplida es de dar y que su inejecución faculta al acreedor para demandarla, interpretando armónicamente el artículo 1489, junto con los incisos segundos de los artículos 1590 y 1814 del Código Civil ${ }^{129}$.

${ }^{129}$ En igual sentido LóPez (2013), p. 87 y LóPEz (2014), p. 623. 
2. ¿Son acertadas y suficientes las premisas sobre las que la jurisprudencia ha asentado la autonomía de la indemnización de daños por incumplimiento contractual?

La revisión jurisprudencial efectuada en el apartado precedente permite constatar que la recepción de la autonomía de la indemnización de daños constituye un cambio de paradigma en el razonamiento de nuestros tribunales que se erige sobre determinadas premisas y consideraciones dogmáticas. Con todo, cabe preguntarse si estas han sido correctamente formuladas y si pueden esgrimirse otras adicionales que permitan sustentarla.

La pregunta es relevante porque hemos advertido que en la actualidad los demandantes invocan en sus escritos dichas premisas, transcribiendo literalmente los considerandos pertinentes de las sentencias que las contienen, quizá con el propósito que la Corte Suprema las reitere y acoja la pretensión indemnizatoria exclusiva.

Como ha quedado de manifiesto en las sentencias que hemos revisado,dicho tribunal ha invocado, aunque en forma entremezclada,la interpretación lógica del artículo 1489, la libre opción del acreedor y la reparación integral del daño que en su momento sugerimos ${ }^{130}$ y que fueron recepcionadas por dicho tribunal, agregando el carácter principal de la indemnización, con el que también concordamos ${ }^{131}$.

No compartimos, en cambio, el alcance que se le ha dado al argumento según el cual la finalidad de la indemnización es la reparación integral del daño, pues se formula en forma muy general y no distingue las hipótesis en que esta resulta determinante. Por otra parte, estimamos que los jueces pueden invocar el principio o regla procesal del iura novit curia como un argumento adicional para justificar la procedencia de la indemnización autónoma en aquellos casos en que el demandante no ha invocado las normas pertinentes para solicitar la pretensión indemnizatoria en forma exclusiva o las ha citado en forma incorrecta, contribuyendo así a fortalecer la observancia de la tutela resarcitoria.

${ }^{130}$ Cfr. LÓPEz (2010), pp. 88-97 y 99-103. Un desarrollo más profundo de tales premisas en LóPEZ (2014 a), pp. 213-241. En lo que concierne a la libre opción del acreedor véase, además, López (2013), pp. 90-93.

${ }^{131}$ Véanse los considerandos cuarto de la sentencia Faúndez Mora con Compañía de Telecomunicaciones de Chile S.A. (2011), décimo cuarto y décimo sexto de la Opazo Lamana con Inmunomédica Laboratorio Ltda. (2010), séptimo de la Asociación de Productores de Huevos de Chile con Banco de Chile (2011), cuarto de la Reyes Valdivia con Escuela de Tripulantes y Portuaria (2012), vigésimo de la Ampuero Ascencio con Castillo Hernández (2013), décimo octavo de la Steffen Cáceres con Fundación Mi Casa (2013) y décimo noveno de la Stange Hoffman con Ripley Puerto Montt (2013), referidos en cada uno de estos casos revisados en el apartado anterior. 
a. Reformulación del principio de reparación integral del daño como argumento para admitir la procedencia de la indemnización

Resulta indiscutido que la finalidad o propósito de la indemnización es la reparación integral de los daños derivados del incumplimiento, en la medida, claro está, que la reparación sea admisible y el daño sea indemnizable. De allí que los autores que han analizado la tipología de los remedios contractuales, subsuman a la indemnización de daños en la categoría de remedio indemnizatorio o resarcitorio, calificación que está en estricta afinidad con la tutela que la indemnización otorga al acreedor ${ }^{132}$.

En su oportunidad, indicamos que dicha finalidad constituía otro argumento para sostener la autonomía de la indemnización ${ }^{133}$, razonamiento que fue recepcionado por la jurisprudencia nacional en las sentencias referidas en el apartado precedente, toda vez que ha indicado que las acciones indemnizatorias, cualquiera sea la naturaleza del objeto de la prestación, pueden impetrarse en forma exclusiva, precisando:

"el legislador ha establecido su procedencia y la forma más usual de interposición, pero no ha prohibido la que en mejor forma repare integralmente el daño derivado del incumplimiento"134.

Agrega además:

“interpretación exegética del artículo 1489 del Código Civil que deriva de una lectura literal del mismo, se contrapone a la reparación integral del acreedor",

recogiendo el planteamiento de alguna doctrina nacional, al que nosotros hemos adherido ${ }^{135}$.

Ciertamente podría criticarse que se aluda a la reparación integral en sede contractual, toda vez que se trata de una denominación que se ha utilizado

${ }^{132}$ En tal sentido Pantaleón (1993), pp. 1727-1728 e Yzouierdo (2003), p. 436.

${ }^{133}$ Cfr. López (2010), pp. 99-103.

${ }^{134}$ Véase, entre otros, los considerandos décimo cuarto de la sentencia Opazo Lamana con Inmunomédica (2010), el séptimo de la Asociación de Productores de Huevos de Chile con Banco de Chile (2011), el duodécimo de la Toro Fuentealba con Concha Sandoval (2012) y el cuarto de la Reyes Valdivia con Escuela de Tripulantes y Portuaria (2012).

${ }^{135}$ Cfr. López (2010), p. 101, n. 90. El primer autor que sostuvo dicho planteamiento fue Carlos Pizarro, indicando lo siguiente: "La interpretación exegética del artículo 1489 responde a una lectura literal del precepto que obstaculiza la reparación integral del acreedor", Pizarro (2007a), p. 216. 
con más frecuencia tratándose de la responsabilidad extracontractual ${ }^{136}$. Sin embargo, resulta evidente que el tribunal ha querido significar que la indemnización por incumplimiento debe tener por propósito colocar al acreedor en la situación más parecida al cumplimiento, salvo que concurran algunas de sus excepciones ${ }^{137}$, cuales son la previsibilidad del daño ${ }^{138}$ y la carga de mitigar ${ }^{139}$.

Precisamente siguiendo este razonamiento y citando a Álvaro Vidal ${ }^{140}$ señala que la indemnización

"permite colmar toda aquella parte del interés del acreedor insatisfecho por causa de incumplimiento, a la que los otros remedios no llegan o no pueden llegar, permitiendo así la realización del interés del acreedor en la prestación, afectada por el incumplimiento".

Lo cierto es que este pasaje que precisa la ventaja de recurrir a la indemnización no se está refiriendo sólo a la indemnización autónoma, toda vez que la indemnización complementaria a la resolución o al cumplimiento específico del contrato también satisface el interés del acreedor en aquella parte que dichas acciones o remedios no lo lograron. Cabe preguntarse, entonces, si es acertado invocar el principio de la reparación integral como argumento que justifique la procedencia de la indemnización exclusiva. En nuestra opinión sigue siendo un argumento pertinente, dado que como expresa Ramón Domínguez este "constituye la idea directriz del sistema indemnizatorio chileno" 141 que admite límites en sede contractual y emana de la interpretación armónica del artículo 1437 del Código Civil que lo

${ }^{136}$ Así, Ruz (2009), pp. 661-677; Domínguez Hidalgo (2010), pp. 671-685 y Pinochet (2013), pp. 589-591. Aludiendo a la reparación integral en sede contractual Domínguez (2010), pp. 9-28, quien precisa que éste es un principio esencial en la responsabilidad civil y "su contenido impone que la medida de la reparación corresponda con la entidad del daño causado, dejando fuera cualquiera otra consideración”, op. cit., p. 9. Con todo, admite la existencia de límites económicos, jurisprudenciales, legales clásicos y convencionales. Un interesante estudio del reconocimiento de este principio en el Derecho Comparado en materia contractual en SAN MARTín (2012), pp. 21-27, especialmente n. 18.

${ }^{137}$ Una idea similar en LARroumet (1996), pp. 722-723 yViney-Jourdain-GHESTIN (2001), pp. 80-88 en que la reparación integral se circunscribe a los perjuicios reparables.

${ }^{138}$ En la doctrina nacional, reconociendo la previsibilidad como límite a la extensión de la indemnización, entre otros, Vidal (2007), pp. 540-542; Pizarro (2007a), p. 220; Domínguez (2010), pp. 18-22; Corral (2010), pp. 176-202; Alcalde (2011), pp. 659-660 y SAN MARTín (2014), pp. 649-668.

${ }^{139}$ Refiriéndose a la carga de mitigar en sede contractual Fuentes (2005), p. 243; VidAl (2008), pp. 437-438 y 449-452 y Gandarillas (2009), pp. 440, 447-449 y Pizarro (2013), pp. 78-79.

${ }^{140}$ VIDAL (2006a), p. 198.

${ }^{141}$ Cfr. Domínguez (2010), p. 27. 
contempla como fuente de las obligaciones y de los artículos 1556 y 1558 del mismo cuerpo legal que consagran tales restricciones ${ }^{142}$.

Sin embargo, dicho principio debe formularse de una manera diversa, distinguiendo al menos dos alternativas. La primera es entender que la indemnización autónoma permite al acreedor obtener la reparación integral "en dinero", facultándolo para disponer de dicha suma en la forma que estime conveniente. En efecto, si demanda la indemnización complementaria solo obtendrá la reparación pecuniaria de los daños extrínsecos o consustanciales, toda vez que quedará excluida de esta el valor de la prestación -o su menor valor, en caso de falta de conformidad-, que será absorbido por el cumplimiento específico ${ }^{143}$. Un fenómeno similar se produce si la indemnización es complementaria a la resolución, salvo que el acreedor celebre una operación de reemplazo y exista una diferencia de precio entre el contrato incumplido y dicha operación, dado que tal diferencia constituye daño intrínseco, pues tiene por objetivo reintegrar al acreedor en su interés en la prestación misma ${ }^{144}$.

Pero también podría ocurrir que el tribunal, siguiendo la tesis de la dependencia o accesoriedad de la indemnización, desestime su ejercicio exclusivo porque no proceden el cumplimiento o la resolución del contrato, en circunstancias que concurren los requisitosde la pretensión 194 indemnizatoria. Sirva como ejemplo el caso Resinas y Terpenos Ltda. con Cía. de Acero del Pacífico S.A. ${ }^{145}$, pues aun cuando la resolución no era procedente, el tribunal debería haber accedido a la suma demandada, resultante de multiplicar el valor fijado por la Superintendencia de Valores y Seguros por el número de acciones compradas en el remate de la bolsa. Otro tanto se advierte en el caso Industrias Magromer S.A. con Sociedad Agrícola Sacor Ltda., toda vez que el tribunal tendría que haber concedido al acreedor el valor de la prestación y el lucro cesante representado por la pérdida de las utilidades que hubiere percibido por entregar la totalidad de los lanares de cuero en tiempo y forma ${ }^{146}$.

${ }^{142}$ En efecto, el artículo 1556 dispone que la indemnización comprende el daño emergente y el lucro cesante, salvo aquellos casos en que la ley la limita en forma expresa al daño emergente. Por su parte, el artículo 1558 consagra la regla de la previsibilidad que delimita la extensión de la indemnización y dibuja el objeto del contrato ocurrido el incumplimiento, lo que le permite al acreedor alcanzar la satisfacción de los intereses protegidos por este.

${ }^{143}$ En un sentido similar indica Álvaro Vidal que si el acreedor demanda la indemnización junto a cualquiera de los otros remedios, quedará excluida de ésta el valor o el menor valor de la prestación que será absorbido por el cumplimiento específico o la reducción del precio, según el caso, cfr. Vidal (2011), p. 767.

${ }^{144}$ Cfr. Morales (2010), pp. 41-42 y Vidal (2011), p. 768.

145 Véase n. 28.

${ }^{146}$ Sobre los hechos de este caso véase n. 30 . 
Es en estos supuestos en que se advierte la necesidad de invocar la reparación integral como argumento para justificar la procedencia de la indemnización autónoma o exclusiva, dado que el acreedor quedará absolutamente insatisfecho y solo la indemnización podrá propender a su satisfacción plena, ubicándolo en una situación lo más parecida al cumplimiento del contrato, toda vez que comprenderá los daños intrínsecos y extrínsecos que logren acreditarse.

b. El iura novit curia: un nuevo argumento en favor de la indemnización autónoma que propende al fortalecimiento de la tutela resarcitoria

Una detenida lectura de las sentencias examinadas en el apartado anterior permite constatar que nuestro máximo tribunal en varias ocasiones se refiere al principio iura novit curia ${ }^{147}$, pero no lo invoca expresamente como argumento para conceder al acreedor la indemnización reclamada en aquellos casos en que este cita de forma incorrecta las normas jurídicas que determinan su procedencia.

$Y$ es que en virtud de este principio, el juez puede aplicar el derecho no alegado por las partes o el derecho correcto si fue erróneamente alegado por estas o, bien, modificar la calificación jurídica de los hechos ${ }^{148}$. Así lo ha reconocido nuestra jurisprudencia en los casos Opazo Lamana con Inmunomédica Ltda., Asociación de Productores de Huevos de Chile con Banco de Chile, Toro Fuentealba con Concha Sandoval, Ampuero Ascencio con Castillo Hernández, indicando al efecto lo siguiente:

“(...) los tribunales son libres para aplicar al caso de que se trata el derecho que estimen pertinente, facultad expresada en el aforismo iura novit curia, esto es, pueden y deben aplicar a la cuestión de hecho (questio facti) las normas legales que la gobiernan (questio juris). Como se dice muy frecuentemente, el juez, en todo caso, al que se le supone por razón de su cargo, perfecto conocedor del derecho, suplirá ex oficio la errónea o imperfecta interpretación del derecho" $" 149$.

${ }^{147}$ Se ha sostenido que es un principio o regula iuris, cfr. Atienza (1996), p. 4); una regla procesal, cfr. Alvarado (1989), pp. 275, 259-270; CAlvinho (2009), p. 226 n. 10-11); una presunción, cfr. EzQUiaga (2000), pp. 17-18) e, incluso, un principio-construcción del Derecho, WróbleWSKI (1989), pp. 153 y 155.

${ }^{148}$ Cfr. Alvarado (1989), p. 275; Esquiaga (2000), pp. 27-28 y Calvinho (2009), p. 245.

${ }^{149}$ Véanse los considerandos undécimo de la sentencia Opazo Lamana con Inmunomédica (2010) y el noveno de la Toro Fuentealba con Concha Sandoval (2012). En lo que se refiere a la recepción del iuranovit curia en nuestra jurisprudencia HunTER (2010), pp. 197-221. 
Claro está que puede existir discusión respecto de la interpretación de un precepto, pero si la ley es clara, el juez resolverá el conflicto sometido a su conocimiento de conformidad a la norma pertinente, aunque las partes no la invoquen, lo que supone su obligación ${ }^{150}$ o deber procesal $^{151}$ de conocer el derecho ${ }^{152}$. Por consiguiente, si el acreedor frente al incumplimiento de una obligación de dar, hacer o no hacer, demanda la indemnización de daños exclusiva, invocando el inciso segundo del artículo 1489 del Código Civil el juez, sin apartarse de la causa de pedir, deberá resolver de acuerdo con las normas aplicables al caso, aunque no hayan sido citadas de manera acertada por los litigantes y concederle la indemnización si ella resulta procedente.

Así, interpretando de modo armónico los incisos segundos de los artículos 1489, 1590 y 1814 del Código Civil relativos a la inejecución de una obligación de dar, podría arribar a la conclusión de que el legislador otorga al acreedor de dicha obligación una opción en favor de la indemnización autónoma, por lo que no procede desestimar dicha solicitud. Por otra parte, si el acreedor frente al incumplimiento de una obligación de hacer o de una obligación de no hacer, no invoca, respectivamente, el artículo 1553 o el artículo 1555 del Código Civil, el juez no puede omitir la aplicación de tales normas. Sin embargo, esto es precisamente lo que 196 ocurre en los casos en que, amparándose en el tenor literal del artículo 1489, deniega la pretensión indemnizatoria que no ha sido precedida de la resolución o el cumplimiento específico del contrato. Sirvan como ejemplo la sentencia de la Corte Suprema en el caso Cuadra Calderón con Céspedes Arteagabeitía y la sentencia de la Corte de Apelaciones de Santiago en Laboratorio de Control Técnico con Celestron Ltda., a las que ya nos hemos referido ${ }^{153}$.

Miradas las cosas desde esta perspectiva, el principio del iura curia novit propende al fortalecimiento de la tutela resarcitoria. Sin embargo, el juez no podría invocarlo para subrogarse en la opción del acreedor, escogiendo una acción diversa a la demandada, so pretexto de fortalecer dicha tutela. En efecto, si bien podría argumentarse que la elección de la acción o remedio que satisface el interés del acreedor por parte del juez garantiza una tutela judicial efectiva, desde una perspectiva procesal, no parece acertado que pueda modificar la opción del acreedor, toda vez que

${ }^{150}$ Cfr. Montero-Gómez-Montón-Barona (2005), pp. 255-256.

${ }^{151}$ Alvarado Velloso se refiere al deber del juez de "sentenciar según la ley, integrándola en caso de silencio u oscuridad, salvo que ella sea inconstitucional”, cfr. Alvarado (1982), pp. 191-201. Por su parte, Juan Montero apunta que el juez tiene el deber de conocer la norma, cfr. MONTERO (2005), p. 36.

${ }^{152}$ Cfr. Calvinho (2009), pp. 229-230.

${ }^{153}$ Véase infra n. 38-39. 
estaría cambiando el objeto de la demanda (causa de pedir) e infringiendo el principio dispositivo y el principio de congruencia sobre los cuales se erige el proceso civil ${ }^{154}$.

Por consiguiente, en el evento de que el deudor no demande la indemnización exclusiva, sino el cumplimiento específico o la resolución, el juez no estaría facultado para imponer tal indemnización, pues se trataría de un medio de tutela diferente al escogido por el acreedor. Distinto sería el caso si el acreedor demandara el cumplimiento o la resolución, y en forma complementaria o subsidiaria la indemnización de daños y aquellos no resulten procedentes. En tal supuesto, si el juez otorgara la indemnización no sólo no contravendría principio procesal alguno -toda vez que se estaría pronunciando sobre una de las pretensiones deducidas por el deudor ${ }^{155}$-,sino que además garantizaría una tutela jurisdiccional efectiva y fortalecería la tutela resarcitoria.

\section{Conclusiones}

De lo expuesto precedentemente, es posible arribar a las siguientes conclusiones:

1. En el último tiempo la Corte Suprema ha revertido la tendencia jurisprudencial que durante décadas postuló el carácter complementario y dependiente de la indemnización por incumplimiento, acogiendo la interposición de la pretensión indemnizatoria en forma autónoma, cualquiera sea el objeto de la prestación incumplida, invocando argumentos tales como: la interpretación lógica del artículo 1489, la libre opción del acreedor, el carácter principal de la indemnización y la reparación integral del daño.

2. Resulta curioso todo este esfuerzo argumentativo, pues la mayoría de los casos en que se ha otorgado la sola indemnización se refie-

${ }^{154}$ En tal sentido Stujs (2001), p. 530 y Tallon (2009), pp. 235-236. Recogiendo tal criterio destaca el voto de minoría de la sentencia pronunciada por la Corte Suprema en este mismo caso, formulado por los ministros Adalis Oyarzún y Sonia Araneda, que sostiene que el juez no puede subrogarse en la opción del acreedor y que debe resolver el asunto sometido a su conocimiento de acuerdo con la acción planteada en el libelo y no a otra diversa (véase el considerando tercero del voto disidente formulado en la sentencia de la Corte Suprema Opazo Lamana con Inmunomédica Laboratorio Ltda. (2010).

${ }^{155}$ Este fue el razonamiento de la Corte Suprema en los casos Opazo con Inmunomédica Ltda. (2010) y Asociación de Productores de Huevos con Banco de Chile (2011), pues como la resolución del contrato no era procedente, admitió la alternativa de acoger la indemnización exclusiva, desestimándola en definitiva, porque no concurrían los presupuestos de la pretensión indemnizatoria. Véase infra II.1. iv. 
ren a la inejecución de una obligación de hacer y en algunos de ellos ni siquiera se reunían sus requisitos, motivo por el cual fue denegada. De allí que estimemos que el verdadero propósito que persiguió nuestro máximo tribunal al pronunciar dichas sentencias fue preparar la línea argumental para sostener la procedencia de la indemnización exclusiva por incumplimiento de una obligación de dar, puesto que, a falta de una norma expresa que faculte al acreedor a optar por ella, esta ha sido discutida.

3. Si bien dicho vuelco jurisprudencial ha permitido fortalecer la tutela resarcitoria, surge la imperiosa necesidad de determinar el contenido indemnizatorio de la pretensión reclamada en cada caso, pues de lo contrario la independencia para impetrar la indemnización exclusiva desdibuja el sistema de acciones o remedios contrctuales que en los últimos años ha intentado de sistematizar la doctrina nacional.

4. Por otro lado, en ocasiones se ha advertido una errónea calificación de la obligación incumplida y una contradictoria determinación del estatuto jurídico aplicable a las obligaciones de dar, lo que acarrea inseguridad jurídica al acreedor al momento de demandar la indemnización exclusiva por incumplimiento contractual, particularmente tratándose de tales obligaciones. Dicho inconveniente determina la necesidad de que los tribunales indiquen en sus sentencias que la obligación incumplida es de dar y admitan su procedencia, interpretando de forma armónica el artículo 1489 junto con los incisos segundos de los artículos 1590 y 1814 del Código Civil.

5. El análisis que hemos efectuado revela que, hasta la fecha, el razonamiento judicial de la autonomía de la indemnización de daños constituye un cambio de paradigma que puede afincarse sobre premisas indubitadas y consideraciones dogmáticas sólidas que permiten proyectarla en el tiempo. Sin embargo, no compartimos el alcance que se le ha dado a la reparación integral del daño, pues se formula en forma muy general y no distingue las hipótesis en que este resulta determinante, motivo por el cual estimamos que debe reformularse en la forma que hemos propuesto.

6. Por otra parte, estimamos que el principio o regla procesal del iura novit curia puede invocarse como un argumento adicional para justificar la procedencia de la indemnización autónoma en aquellos casos en que el demandante no ha invocado las normas pertinentes para solicitar la pretensión indemnizatoria en forma exclusiva o las ha citado incorrectamente, fortaleciéndose así la observancia de la tutela resarcitoria. 


\section{BibliografíA}

Abeliuk Manasevich, René (2010). Las Obligaciones. $5^{\text {a }}$ ed. Santiago: Editorial Jurídica de Chile, tomo II.

Alcalde Silva, Jaime (2011). "La responsabilidad contractual en el Código Civil: del particularismo al régimen general”, en Gonzalo Figueroa Yañez, Enrique Barros Bourie, Mauricio Tapia Rodríguez (coords.). Estudios de Derecho Civil VI. Santiago: Editorial Abeledo Perrot LegalPublishing.

Alcalde Silva, Jaime (2012). "La reaparición de la cosa perdida y la facultad del acreedor para reclamarla". Revista de Derecho de la Pontificia Universidad Católica de Valparaíso, $\mathrm{N}^{\circ} 38$. Valparaíso. Diciembre.

Alvarado Velloso, Adolfo (1989). Introducción al estudio del Derecho Procesal. Santa Fe: Editorial Rubinzal-Culzoni, tomo I.

Alessandri Rodríguez, Arturo, Manuel Somarriva Undurraga, Antonio VodaNOvic Hadlicka (2004). Tratado de las Obligaciones. $2^{\mathrm{a}}$ ed. Santiago: Editorial Jurídica de Chile, vol. II: Del cumplimiento e incumplimiento de las obligaciones, de la protección de los derechos del acreedor, de la insolvencia y las formas de pago de los deudores insolventes

Arismendi Lairet, Pedro (1939). "Autonomía de la acción de daños y perjuicios contractuales". Boletín de la Academia de Ciencias Políticas y Sociales. Vol. IV, Caracas.

Atienza, Manuel, Juan Ruiz Manero (1996). Las piezas del Derecho. Teoría de los enunciados jurídicos. Barcelona: Editorial Ariel.

BaraOna GonZÁlez, Jorge (1997). "Responsabilidad contractual y factores de imputación de daños: apuntes para una re-lectura en clase objetiva". Revista Chilena de Derecho, vol. 24. N 1. Santiago. Abril.

Barcia Lehmann, Rodrigo (2008). Lecciones de Derecho Civil Chileno. Santiago: Editorial Jurídica de Chile, tomo III: De la teoría de las Obligaciones.

Barros Bourie, Enrique (2008). "Finalidad y alcance de las acciones y los remedios contractuales", Alejandro GuZmán Brito (ed.). Estudios de Derecho Civil III. Santiago: Editorial LegalPublishing.

Bustamante Salazar, Luis (2005). "Autonomía del equivalente pecuniario o su integración dentro de la indemnización de daños", en Juan VARAS Braun, Susan Turner Saelzer (eds.). Estudios de Derecho Civil I. Santiago: Editorial LexisNexis.

Calvinho, Gustavo (2009). El brocárdico iura novit. Madrid: Revista de Derecho Procesal.

Castilla Barea, Margarita (2001). La imposibilidad de cumplir los contratos. Madrid: EditorialDykinson.

Contardo González, Juan Ignacio (2014). "Independencia de la acción de perjuicios en sede contractual. Corte Suprema, Primera Sala (Civil), 10 de septiembre de 2013, Rol 885-2013". Revista Chilena de Derecho Privado, N $^{\circ} 22$, Santiago. Julio. 
Corral Talciani, Hernán (2010). Contratos y daños por incumplimiento. Santiago: Editorial Abeledo Perrot, LegalPublishing.

Correa Fuenzalida, Guillermo (1933). Teoría de las Obligaciones. Santiago: versión taquigráfica de clases.

Coviello Jr., Leonardo (1935). "Risoluzione per inadempimento: retroattivitá e risarcimento del danno". Rivista di Diritto Civile, N²7, Milano. GennaioFebbraio.

Cubides-Camacho, Jorge (2009). Obligaciones, 6a ed. Bogotá: Editorial Pontificia Universidad Javeriana.

Claro Solar, Luís (1937). Explicaciones de Derecho Civil y Comparado. Santiago: Editorial Imprenta Nascimiento, tomo IX: Las obligaciones II.

De la Maza Gazmuri, Iñigo (2007). "Compraventa, incumplimiento y remedios”. Revista Chilena de Derecho Privado, N 9, Santiago. Diciembre.

De la Maza Gazmuri, Iñigo (2014). "Reglas complejas para un caso de incumplimiento simple". Análisis Jurídico, Contratos y Responsabilidad. Disponible en www.elmercurio.com/Legal/Noticias/Analisis-Juridico/2014/07/25/ Reglas-complejas-para-un-caso-de-incumplimiento-simple.aspx\#. [Fecha de consulta: 25 de julio de 2014].

De la Maza Gazmuri, Iñigo-Vidal Olivares, Álvaro (2014). “Propósito práctico, incumplimiento contractual y remedios del acreedor con ocasión de tres recientes sentencias de la Corte Suprema”. Ius et Praxis. $\mathrm{N}^{\circ}$ 20, $\mathrm{N}^{\circ} 1$. Talca.

Díez-Picazo y Ponce de León, Luis María (2008). Fundamentos del Derecho Civil Patrimonial II. Las relaciones obligatorias. $6^{\text {a }}$ ed. Madrid: Editorial Thomson Reuters.

Domínguez Hidalgo, Carmen (2010). "El principio de reparación integral del daño y su contenido: algunas consecuencias para el derecho chileno", en Departamento de Derecho Privado Universidad de Concepción (coord.). Estudios de Derecho Civil V. Santiago: Editorial Abeledo Perrot LegalPublishing.

Domínguez ÁGuila, Ramón (2010). "Los límites al principio integral de la reparación”. Revista Chilena de Derecho Privado, N 15, Santiago, Diciembre.

Elorriaga De Bonis, Fabián (2012). "Las dificultades de los remedios por incumplimiento contractual en la experiencia chilena", en Carlos A. Sото Coaguila (coord.). Teoría General del contrato. Homenaje al profesor doctor Ricardo L. Lorenzetti. Buenos Aires: La Ley, tomo II.

EzQUiaga GanuZas, Francisco Javier (2000) “Iura Novit curia” y aplicación judicial del derecho. Valladolid: Editorial Lex Nova.

Fuentes Guíñez, Rodrigo (2005). "El deber de evitar o mitigar el daño”. Revista de Derecho. No 217-218, Concepción.

Fueyo LANERI, Fernando (2004). Cumplimiento e incumplimiento de las obligaciones, $3^{\mathrm{a}}$ ed. Santiago: Editorial Jurídica de Chile.

Gandarillas SERAni, Cristián (2009)."Algunas consideraciones acerca del deber de mitigación o minimización del daño frente al incumplimiento contractual”, 
en Carlos Pizarro Wilson (coord.), Estudios de Derecho Civil IV. Santiago: Editorial LegalPublishing.

Genicon, Thomas (2007). La résolution du contrat pour inexécution. Paris: Editorial LGDJ.

Grosser, Paul (2000). Les remèdes à l'inexécution du contrat. Essai de classification. thèse. Paris: Université Paris I.

Hunter Ampuero, Iván (2010). "Iura novit curia en la jurisprudencia civil chilena”. Revista de Derecho. Vol. XXIII. $\mathrm{N}^{\circ} 2$, Valdivia.

Kummerow, Gert (1999). "Esquema del daño contractual resarcible según el sistema normativo venezolano", en AA.VV. Indemnización de daños y perjuicios. Caracas: Editorial Fabretón.

LAMARCA MarquÉs, Albert (2001). El hecho del acreedor y la imposibilidad de laprestación. Bolonia: Editorial Publicaciones del Real Colegio de España.

Larroumet, Christian (1996). Droit Civil. Tome III. Les Obligations. Les contrats. $3^{\text {a }}$ ed. Paris: Editorial Económica.

LÓPEz DíAz, Patricia Verónica (2010). "La indemnización compensatoria por incumplimiento de los contratos bilaterales como remedio autónomo en el Derecho Civil chileno". Revista Chilena de Derecho Privado, N 15. Santiago. Diciembre.

LóPez DíAz, Patricia Verónica (2013). "El término esencial y su incidencia en la determinación de las acciones o remedios por incumplimiento contractual del acreedor a la luz del artículo 1489 del Código Civil chileno". Revista Chilena de Derecho Privado. N $^{\circ}$ 20. Santiago. Julio.

LóPez DíAz, Patricia Verónica (2014a). La autonomía de la indemnización de daños por incumplimiento de un contrato bilateral en el código civil chileno. Tesis doctoral inédita. Valparaíso.

LóPez DíAz, Patricia Verónica (2014b)."El aliud pro alio: un supuesto de indemnización de daños autónoma o exclusiva frente al incumplimiento del deudor”. Estudios de Derecho Civil IX. Santiago: Editorial LegalPublishing Thomson Reuters.

Luminoso, Angelo (1990). "Risoluzione per inadempimento", en Francesco Galgano, Commentario del Codice civile Scialoja-Branca, Libro cuarto, Delle obbligazioni Della risoluzione per inadempimento, T. I, 1 artículo 1453 -1454. Roma: Editorial Zanichelli.

Llamas Pombo, Eugenio (1999). Cumplimiento por equivalente y resarcimiento del daño al acreedor: (entre la aestimatio rei y el id quod interest. Madrid: Editorial Trivium.

Mantilla Espinosa, Fabricio-Francisco Ternera Barrios (2007). "La resolución”, en Fabricio Mantilla Espinosa, Francisco Ternera Barrios (dirs.). Los contratos en el Derecho Privado. Bogotá: Editorial Legis.

Mélich Orsini, José (2007). La resolución del contrato por incumplimiento. 2a ed. Caracas: Editorial Ciencias Políticas y Sociales.

Montero Aroca, Juan, Juan Luís Gómez Colomer, Alberto Montón Redondo, Silvia Barona Vilar (2005). Derecho Jurisdiccional. II. Proceso Civil. $14^{\mathrm{a}}$ ed. Valencia: Editorial Tirant Lo Blanch. 
Morales Moreno, Antonio Manuel (2006). "Evolución del concepto de obligación en el derecho español", en Antonio Manuel Morales Moreno. La modernización del Derecho de obligaciones. Navarra: Editorial Civitas.

Morales Moreno, Antonio Manuel (2010). Incumplimiento del contrato y lucro cesante. Pamplona: Editorial Civitas.

Ospina Fernández, Guillermo (2001). Régimen General de las Obligaciones, $7^{\mathrm{a}}$ ed. Bogotá: Editorial Temis.

Oviedo Albán, Jorge (2009). "Exclusión tácita de la ley aplicable e indemnización de daños por incumplimiento de un contrato de compraventa internacional (a propósito de reciente jurisprudencia chilena)". Revista Colombiana de Derecho Internacional. $\mathrm{N}^{\circ} 14$, Bogotá. Enero-junio.

Pantaleón Prieto, Fernando (1993). "Las nuevas bases de la responsabilidad civil". Anuario de Derecho Civil. Fascículo 4. Vol. 46. Madrid. Diciembre.

Peñallillo Arévalo, Daniel (2003). Las Obligaciones. Teoría general y clasificaciones. La resolución por incumplimiento. Santiago: Editorial Jurídica de Chile.

Peñailillo Arévalo, Daniel (2009). "Responsabilidad contractual objetiva", en Carlos Pizarro Wilson (coord.). Estudios de Derecho Civil IV. Santiago: Editorial LegalPublishing.

Pinochet Olave, Ruperto (2013). "El principio de reparación integral del daño y su relación con las garantías constitucionales", en Carmen Domínguez 202 Hidalgo, José González Castillo, Marcelo Barrientos Zamorano, Juan Luis Goldenberg Serrano (coords.), Estudios de Derecho Civil VIII. Santiago: Editorial LegalPublishing Thomson Reuters.

Pinori, Alessandra (2001). Il danno contrattuale. II.Criteri di valutazione. Tecniche e regole giudiziali di liquidazione. Padova: Editorial Cedam.

PizArro Wilson, Carlos (2007a). "La responsabilidad contractual en el Derecho Chileno", en Fabricio Mantilla (coord.). Problemas de Derecho de los Contratos. Bogotá: Editorial Legis.

Pizarro Wilson, Carlos (2007b). "Por la autonomía de la acción indemnizatoria por incumplimiento contractual. Sentencia de la Corte de Apelaciones de Punta Arenas, 9 de Enero de 2007". Revista Chilena de Derecho Privado. N 9. Santiago. Diciembre.

Pizarro Wilson, Carlos (2013). "Contra el fatalismo del perjuicio. A propósito del deber de mitigar el daño". Revista de Derecho de la Pontificia Universidad Católica de Valparaíso. $\mathrm{N}^{\circ}$ 41. Valparaíso. Diciembre.

Pothier, Robert (1839). Tratado de las obligaciones. Primera Parte. (trad. cast.). Barcelona: Imprenta y Litografía de J. Roger.

Ramos Pazos, René (2008), De las Obligaciones, $3^{\mathrm{a}}$ ed. Santiago: Editorial LexisNexis.

Rémy, Philippe (2009). L' inexécution du contrat, en François Terré (ed.). Pour une réforme du droit des contrats. Paris: Editorial Dalloz.

Rémy-Corlay, Pauline (2005).“Exécution et réparation: deux concepts?”. Revue des Contrats. $\mathrm{N}^{\circ}$ 1. Paris. Janvier. 
RuZ LÁrtiga, Gonzalo (2009). "La reparación integral del daño: ¿̇mito o realidad?", en Carlos Pizarro Wilson (coord.). Estudios de Derecho Civil IV. Santiago: Editorial LegalPublishing.

SAN MARTín, Lilian (2012). La carga del perjudicado de evitar o mitigar el daño. Estudio Histórico-comparado. Bogotá: Editorial Universidad Externado de Colombia.

SAN MARTín, Lilian (2014). La previsibilidad como límite al resarcimiento del daño por incumplimiento contractual en Estudios de Derecho Civil IX. Santiago: Editorial LegalPublishing Thomson Reuters.

Sánchez Castro, David (2010). "El cumplimiento por equivalente:ciun modo de evitar los requisitos imprescindibles de toda pretensión indemnizatoria?". Anuario de Derecho Civil. fascículo 4. Vol. 63. Diciembre.

Sicchiero, Gianluca (2007). La risoluzione per inadempimento Artt. 1453-1459, in Piero Schlesinger. Il Codice Civile, Comentario dirigido por Piero Schlesinger. Milano: Editorial Giuffrè.

Stijns, Sophie (2001). "La résolution pour inexécution en droit belge: conditions et mise en oeuvre", en Marcel FonTAIne, Geneviève Viney (eds.). Les sanctions de t inexécution des obligations contractualle, Etudes de droit comparé. Bruxelles: LGDJ.

TALLON, Denis (1994). "Linexécution du contracté: pour une autre présentation". Revue Trimestrielle de Droit Civil. $\mathrm{N}^{\circ}$ 2. Paris. Avril-Juin.

Troncoso Larronde, Hernán (2007). De las Obligaciones, $5^{\text {a }}$ ed. Santiago: Editorial LexisNexis.

Verdera Server, Rafael (1995). El cumplimiento forzoso de las obligaciones. Bolonia: Editorial Publicaciones del Real Colegio de España.

Vial del Río, Víctor Manuel (2007). Manual de las Obligaciones en el Código Civil Chileno. $2^{\mathrm{a}}$ ed. Santiago: Editorial Biblioteca Americana.

Vidal Olivares, Álvaro (2006a). La protección del comprador: régimen de la Convención de Viena y su contraste con el Código Civil. Valparaíso: Ediciones Universitarias de Valparaíso.

Vidal Olivares, Álvaro (2006b). "La pretensión de cumplimiento específico y su inserción en el sistema de remedios por incumplimiento en el Código Civil", en Hernán Corral, María Sara Rodríguez (eds.). Estudios deDerecho Civil II. Santiago: Editorial Lexis Nexis.

Vidal Olivares, Álvaro (2007)."El incumplimiento de obligaciones con objeto fungible y los remedios del acreedor afectado. Un intento de relectura de las disposiciones del código civil sobre incumplimiento", en Alejandro GuZMán BRITo (ed.). El Código Civil de Chile (1855-2005). Santiago: Editorial LexisNexis.

Vidal Olivares, Álvaro (2008). "La carga de mitigar las pérdidas del acreedor y su incidencia en el sistema de remedios por incumplimiento", en Alejandro Guzmán Brito (ed.). Estudios de Derecho Civil III. Santiago: Editorial LegalPublishing.

Vidal Olivares, Álvaro (2011a). "La indemnización de daños y la opción del acreedor del acreedor frente al incumplimiento" en Gonzalo FigueroA YA- 
Ñez, Enrique Barros Bourie, Mauricio Tapia Rodríguez (coords.), Estudios de Derecho Civil VI. Santiago: Editorial AbeledoPerrot LegalPublishing.

Vidal Olivares, Álvaro (2014). "La indemnización de daños por incumplimiento y estar "contractualmente obligado". Estudios de Derecho Civil IX. Santiago: Editorial LegalPublishing Thomson Reuters.

VINEY, Geneviène (2001). "La responsabilité contractuelle en question”, in Gilles Goubeaux, Jaques GHestin. Études offertes à Jacques Ghestin "Le contrat au début du XXIe siècle".Paris: LGDJ.

Viney, Geneviève, Patrice Jourdain, Jacques GHestin (2001). Les obligations. Les effets de la responsabilitéen Ghestin, Jacques, Traité de droit civil. $2^{\mathrm{a}}$ ed. Paris: LGDJ.

Vío VÁsQuez, Efraín (1945). Obligaciones condicionales. Doctrina-jurisprudencialegislación comparada. Concepción: Editorial Escuela Tipográfica Salesiana.

Wróblewski, Jerzy (1989). "Sentido" y "hecho" en el derecho. San Sebastián: Editorial de la Universidad del País Vasco.

YzQuierdo Tolsada, Mariano (2003). "Consecuencias del incumplimiento. En particular, reflexiones sobre los remedios resolutorios por el equivalente, los remedios resarcitorios y ciertas medidas de presión sobre el deudor incumplidor", en Carlos Vattier Fuenzalida, José María de la Cuesta Cáceres, José María Caballero Rute, (eds.). Código Europeo de Los Contratos. Madrid: Editorial Dykinson.

\section{Jurisprudencia citada}

Agroindustria San Vicente S.A. con Exportadora Aconcagua Ltda. (2009): Corte Suprema, 30 de septiembre de 2009 (casación en el fondo), Microjuris No 21689.

Ampuero Ascensio con Castillo Hernández (2013): Corte Suprema, 28 de enero de 2013 (casación en el fondo), LegalPublishing $N^{\circ}$ CL/JUR/174/2013.

Aranda y MajorDrilling Chile S.A.(2007): Corte de Apelaciones de La Serena, 3 de marzo de 2008 (recurso de apelación), Legalpublishing $\mathrm{N}^{\circ} 38402$.

Asociación de Productores de Huevos de Chile y Banco de Chile (2010): Corte Suprema, 31 de agosto de 2011 (casación en el fondo), Vlex N 333763730.

Barrios con Rozé (1868): Corte de Apelaciones de Valparaíso, 17 de octubre de 1867 (recurso de apelación), Gaceta de los Tribunales, sección 815, Santiago.

Barthet con Paine (1880): Corte de Apelaciones de Santiago, 28 de agosto de 1880 (recurso de apelación), Gaceta de los Tribunales, S. 1972, Santiago.

Bustos con Betancourt (2006): Corte Suprema, 23 de marzo de 2006 (casación en el fondo), Legalpublishing $\mathrm{N}^{\circ} 33997$.

Carrasco con Clínica Dávila y Servicios Médicos S.A. (2008): Corte de Apelaciones de Santiago, 1 de octubre de 2008 (casación en la forma y apelación), Legalpublishing $\mathrm{N}^{\mathrm{o}} 40377$.

Cataldo con Empresa Portuaria San Antonio (2010): Corte Suprema, 5 de enero de 2010 (casación en el fondo), Legalpublishing $\mathrm{N}^{\circ} 43037$. 
Celestron Ltda. con Laboratorio de Control Técnico (2013): Corte de Apelaciones de Santiago, 12 de septiembre de 2013 (recurso de apelación), Gaceta Jurídica $\mathrm{N}^{\circ} 399$, Santiago.

Claudio Moron Moscote con Conservas California S.A. (1977): Corte Suprema de Justicia Colombiana, 3 de noviembre de 1977 (casación en el fondo), Gaceta Judicial, tomo CLV, $\mathrm{N}^{\circ}$ 2396, Santiago.

Coexpan Chile S.A. y Banco Security (2009): Corte Suprema, 23 de marzo de 2009 (casación en el fondo), Microjuris N MJJ19726.

Coexpan Chile S.A. con Banco Security (2014): Corte Suprema, 15 de mayo de 2014 (casación en el fondo), Legal Publishing No CL/JUR/2572/2014.

Corral y Cía. de Teléfonos Chile y Comercial Publiguías (1978): Corte la Suprema, 14 de diciembre de 1978 (recurso de queja), Fallos del Mes, № 241, año $\mathrm{xx}$, Santiago.

CoulonTopp con Fernández Briso (2009): Corte de Apelaciones de Temuco, 22 de octubre de 2009 (recurso de apelación), Legalpublishing $\mathrm{N}^{\circ} \mathrm{CL} / \mathrm{JUR}$ / 2492/2009).

Cuadra Calderón con Céspedes Arteagabeitía (2013): Corte Suprema, 30 de octubre 2013 (casación en el fondo), Vlex $\mathrm{N}^{\circ} 473555966$.

Faúndez Mora con Compañía de Telecomunicaciones de Chile S.A. (2011): Corte Suprema, 20 de junio de 2011, rol 3957-2011 (casación en el fondo), no publicada.

Faúndez Mora con Compañía de Telecomunicaciones de Chile S.A. (2011): Corte de Apelaciones de Concepción, 29 de marzo de 2011, rol 1258-2011 (recurso de apelación), Legalpublishing $\mathrm{N}^{\circ} 48526$.

Fernández Chaparro con Méndez Maturana (2010):Corte de Apelaciones de La Serena, 27 de agosto de 2010 (recurso de apelación), Legalpublishing $\mathrm{N}^{\circ} \mathrm{CL}$ /JUR/9149/2010.

Fisco de Chile con Sociedad Ingeniería y Construcción del Sur S.A. (2011): Corte de Apelaciones de Talca, 28 de noviembre de 2011 (recurso de apelación), no publicada.

Fisco de Chile con Sociedad Ingeniería y Construcción del Sur S.A. (2012): Corte Suprema, 20 de noviembre de 2012 (casación en el fondo), Legal Publishing $\mathrm{N}^{\circ} \mathrm{CL} / \mathrm{JUR} / 2468 / 2012$.

Industria Magromer Cueros y Pieles S.A. con Sociedad Agrícola Sacor Limitada (2007): Corte de Apelaciones de Punta Arenas, 9 de enero de 2007 (recurso de apelación), Legalpublishing $\mathrm{N}^{\circ} 35743$.

Instituto de Normalización Previsional con Banco Santander Chile(2006): Corte Suprema, 26 de diciembre de 2006 (casación en el fondo), Microjuris $\mathrm{N}^{\circ} \mathrm{MJJ}$ 9037.

Juica y otros con Liceo San Francisco de Asís y Otros (2004): Corte Suprema, 28 de julio de 2004 (casación en la forma y casación en el fondo), Legalpublishing $\mathrm{N}^{\mathrm{O}} 30585$. 
Laboratorio de Control Técnico Llai Llai con Celestron Ltda. (2014): Corte Suprema, 26 de noviembre 2014 (casación en el fondo), disponible en http:// suprema.poderjudicial.cl/SITSUPPORWEB/InicioAplicacion.do

Mac Auliffe y Compañía con Salinas (1990): Corte Suprema, 18 de mayo de 1900 (recurso de apelación), Gaceta de los Tribunales, tomo I, S. 748, Santiago.

Muñoz Cerda con Massu Massu(2012): Corte de Apelaciones de Valparaíso, 8 de agosto de 2012 (recurso de apelación), Legal Publishing $\mathrm{N}^{\circ}$ : CL/JUR/1658/ 2012 .

Opazo Lamana con Inmunomédica Laboratorio Limitada (2010): Corte Suprema, 7 de diciembre de 2010 (casación en la forma y casación en el fondo), Legalpublishing $\mathrm{N}^{\circ} 47448$.

Oviedo y Sociedad Agrícola Sarcor Limitada (2008): Corte Suprema, 22 de septiembre de 2008 (casación en el fondo), Legalpublishing $\mathrm{N}^{\circ} 39756$.

Reyes Valdivia, Rodrigo con Escuela de Tripulantes y Portuaria (2012): Corte Suprema, 10 de julio de 2012 (casación en el fondo), Legal Publishing $\mathrm{N}^{\circ} \mathrm{CL} /$ JUR/1308/2012.

Segovia Barrientos con Arroyo López: Corte Suprema, 25 de junio de 2012 (casación en el fondo), Legal Publishing $\mathrm{N}^{\circ} \mathrm{CL} / \mathrm{JUR} / 1179 / 2012$.

Segovia Barrientos y Saez Arroyo (2011): Corte de Apelaciones de Valparaíso, 1 de junio de 2011 (recurso de apelación), Legalpublishing $\mathrm{N}^{\circ} 49795$.

Seguros Generales S.A. con Transportes Aduana Ltda. (2009): Corte Suprema, 8 de junio de 2009 (casación en el fondo), no publicada.

Silva con Lafrenz y Díaz (1910): Corte de Apelaciones de Valparaíso, 14 de mayo de 1910 (recurso de apelación), Gaceta de los Tribunales, tomo I, S. 322, Santiago.

Sociedad Pesquera Esmeralda S.A. y Cofrina S.A. (1990): Corte de Apelaciones de Punta Arenas, 2 de marzo de 1990 (recurso de apelación), Revista de Derecho y Jurisprudencia, t. 87.

Sociedad Resinas y Terpenos Ltda. y Cía. de Aceros del Pacífico S.A. (1993): Corte Suprema, 27 de enero de 1993 (casación en la forma y casación en el fondo), Revista de Derecho y Jurisprudencia, t. 90.

Stange Hoffman con Ripley Puerto Montt (2013): Corte Suprema, 2 de octubre de 2013 (casación en la forma), Microjuris N MJJ36038.

Steffen Cáceres con Fundación Mi Casa (2013): Corte Suprema, 10 de septiembre 2013 (casación en el fondo), $\mathrm{N}^{\circ}$ LegalPublishig: CL/JUR/2008/2013.

Tecdia S.A. con Aceites del Sur S.A. (2005): Tribunal Supremo Español, 21 de octubre de 2005 (casación en el fondo), Revista de Jurisprudencia Aranzadi 2006/ 1689.

Torre Fuentealba con Concha Sandoval (2012): Corte Suprema, 13 de junio de 2012, (casación en el fondo y casación en el fondo), Legalpublishing $\mathrm{N}^{\circ} \mathrm{CL} /$ JUR/1092/2012. 
Transportes Aeropuerto Express Limitada y LADECO S.A. (2007): Corte Suprema, 16 de agosto de 2007, (casación en el fondo), Legalpublishing $\mathrm{N}^{\circ} 38928$.

Virgilio y otros con Schiavetti y Hermanos (1894): Corte de Apelaciones de Valparaíso, 15 de diciembre de 1894, (recurso de apelación), Gaceta de los Tribunales, tomo III, S. 3687, Santiago.

Warncken con Ferrer (1993): Corte Suprema, 28 de julio de 1933, (casación en la forma y casación en el fondo), Revista de Derecho y Jurisprudencia de 1933, tomo 30, sección primera, pp. 495-501, Santiago.

Zorín S.A. con Compañía Siderúrgica Huachipato S.A. (2009): Quinto Juzgado Civil de Santiago, 30 de noviembre de 2009, no publicada.

Zorín S.A. con Compañía Siderúrgica Huachipato S.A. (2012): Corte de Apelaciones de Santiago, 11 de enero de 2012, (casación en la forma y recurso de apelación), no publicada.

Zorín S.A. con Compañía Siderúrgica Huachipato S.A. (2012): Corte Suprema, 31 de octubre de 2012 (casación en la forma y casación en el fondo), Legal Publishing $\mathrm{N}^{\circ}$ CL/JUR/2412/2012. 